\title{
The U Visa's Failed Promise for Survivors of Domestic Violence
}

\author{
Natalie Nanasi ${ }^{\dagger}$
}

\begin{abstract}
Recognizing the unique vulnerabilities of immigrants who become victims of crime in the United States, Congress enacted the $U$ visa, a form of immigration relief that provides victims, including survivors of domestic violence, a path to lawful status. Along with this humanitarian aim, the $U$ visa was intended to aid law enforcement in efforts to investigate and prosecute crime, based on the notion that victims without legal status might otherwise be too fearful to "come out of the shadows" by reporting offenses to the police. Although these two goals were purportedly coequal, in practice, by requiring survivors to cooperate with law enforcement in order to obtain U nonimmigrant status, benefits to police and prosecutors are achieved at the expense of the victims Congress sought to protect, exacerbating the very vulnerabilities the $U$ visa was intended to address.

This article posits that the marginalization of immigrant victims' interests should have been foreseen. $U$ visa requirements are analogous to other mandatory interventions in cases of domestic violence that have disempowered and destabilized survivors, particularly poor women of color. In tracing the history of the public response to domestic violence, from the time when spousal abuse was ignored or condoned to the overcorrection that has led to compulsory state involvement in women's lives, it becomes clear that the U visa has perpetuated the swing of the pendulum away from victim autonomy and toward an aggressive criminal justice response to intimate partner violence. This article details why such a shift is particularly damaging for immigrant survivors due to language barriers, complicated relationships with police, familial ties and
\end{abstract}

$\dagger \quad$ Assistant Professor and Director, Judge Elmo B. Hunter Legal Center for Victims of Crimes Against Women, SMU Dedman School of Law. The author thanks the participants of the Texas Legal Scholars Workshop and the NYU Clinical Law Review Writers' Workshop, Kate Sablosky Elengold, Michele Gilman, Laurie Kohn, Tamara Kuennen, Lydia Watts, Leigh Goodmark, and Nathan Cortez for their immensely helpful feedback. I am also grateful for the research assistance of Donna Wolff, Pooja Vasudev, Samantha Johnson, and Tiffany Clark as well as the generosity of the Clark J. Matthews, II Faculty Research Endowment Fund. 
economic constraints. This article then proposes novel solutions that mitigate the harmful effects of the $U$ visa certification requirement and break away from ineffective conventions surrounding assistance for survivors of domestic violence.

INTRODUCTION .274

I. THE U VISA

A. Statutory Requirements ……………............................................27

B. The U Visa and Domestic Violence: A Legislative History ............280

C. Domestic Violence and Immigrant Women: Prevalence, Risk, and

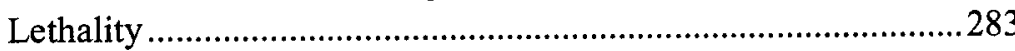

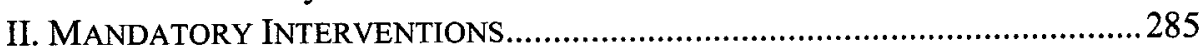

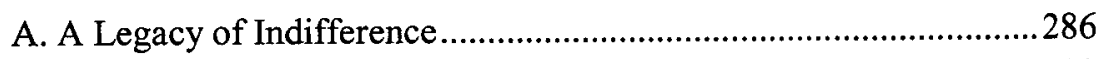

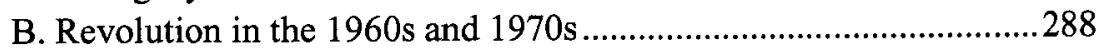

C. Modern Approaches......................................................................290

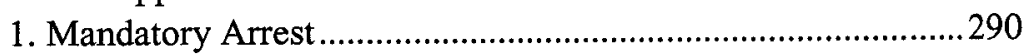

2. Mandatory, or No Drop, Prosecution........................................291

3. Benefits and Critiques..............................................................292

III. BARRIERS TO COOPERATION FACED BY IMMIGRANT SURVIVORS OF

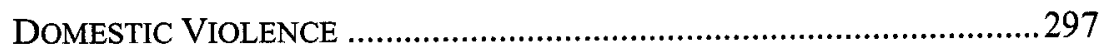

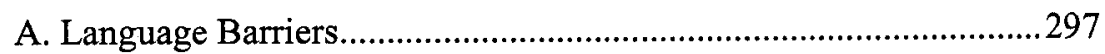

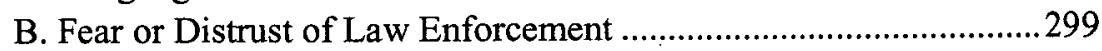

1. Experiences in Country of Origin ............................................299

2. Inequality and Bias in Policing ...............................................300

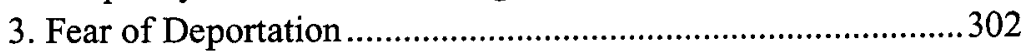

i. Local Police as Immigration Enforcement ...........................302

ii. Abuse of Discretion in U Visa Certification.........................303

iii. Deportation as a Tool of Abuse .........................................306

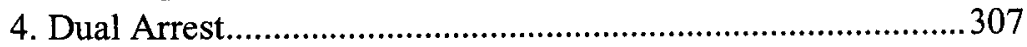

C. Family Fracturing, Economic Consequences and Isolation..............308

D. Separation Violence........................................................................311

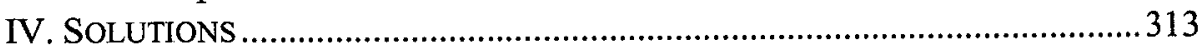

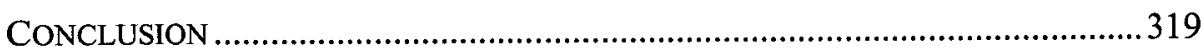

\section{INTRODUCTION}

When Congress created the $U$ visa, a form of immigration relief available to victims of crime who cooperate in the investigation or prosecution of their perpetrators, it had two stated aims: to protect immigrant victims and to assist 
law enforcement agencies. Premised on the notion that non-citizen victims, survivors of domestic violence in particular, would be unwilling to identify themselves to the police for fear of deportation, the U visa promised a pathway to lawful immigration status that was intended to bring crime victims "out of the shadows" and into safety. The cooperation of immigrant victims, which would ideally lead to the identification, arrest, and eventual prosecution of criminals, would in turn be a benefit to both the state and the public at large.

Although these aims were undoubtedly noble, they were squarely in conflict. Receipt of $U$ nonimmigrant status is conditioned upon compulsory and continuing cooperation with law enforcement, and the desire to engage with the state in this manner does not reflect the realities of many immigrant survivors of domestic violence. In fact, this article, situated in a feminist critique, will show that requiring battered immigrant women ${ }^{1}$ to cooperate with law enforcement in order to receive $U$ visas has ironically made the immigration relief that was specifically created to help them a source of increased risk and danger. A review of previously-enacted mandatory law enforcement interventions in cases of intrafamily violence will reveal that the incompatibility of Congress' goals should not have come as a surprise. The coerced interaction with law enforcement that stems from the $U$ visa is analogous to a long line of mandatory interventions that have proven inadequate in protecting and supporting survivors of domestic violence.

Section II will provide critical background on U nonimmigrant status, including what a victim must prove and what evidence she must provide to the U.S. Citizenship and Immigration Services (USCIS) in order to receive the visa and the benefits that accrue upon receipt. A brief legislative history of the $U$ visa is also included - a record which highlights how a visa that is technically available to victims of a wide range of crimes has been inextricably intertwined with the issue of domestic violence against immigrant women.

Section III explains and provides context for understanding the origin and current role of mandatory interventions in the fight against domestic violence in the United States. After decades of indifference and even hostility towards victims of family abuse who sought help from law enforcement, the feminist

1. While both men and women experience intimate partner violence, women are impacted at significantly higher rates: one in four women have been the victim of severe physical violence by their partners, as opposed to one in seven men. See CTRS. FOR DISEASE CONTROL AND PREVENTION,

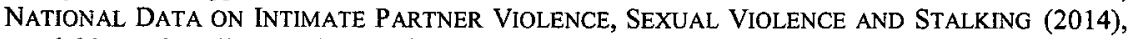
available at http://www.cdc.gov/violenceprevention/pdf/nisvs-fact-sheet-2014.pdf [https://perma .cc/6B2R-TQ5H]. In fact, between 1994 and 2010, four out of five victims of domestic violence were female. See Statistics: Get the Facts \& Figures, NAT'L DOMESTIC VIOLENCE HotLINE http://www.thehotline.org/resources/statistics/ [https://perma.cc/HA5F-F6Q5] (last visited Feb. 24, 2018). Other sources indicate that 85 percent of victims of domestic violence are women. BUREAU of Justice Statistics, CRIME DATA BRIEF, InTIMATE PARTNER VIOLENCE, 1993-2001 (2003), available at https://www.bjs.gov/content/pub/pdf/ipv01.pdf [https://perma.cc/WG69-NMRG]. Therefore, although this article recognizes that both men and women experience domestic violence, and that intimate partner abuse occurs in same-sex relationships, it will often use the feminine pronoun when referring to victims and the masculine pronoun when describing perpetrators. 
movement of the 1960s and 1970s ushered in a new era and approach in which domestic violence was treated as a serious and actionable offense. Enticed by funding opportunities provided by the 1994 Violence Against Women Act (VAWA), jurisdictions began to enact mandatory arrest and "no drop" prosecution policies in an effort to remove discretion from individual officers and improve the criminal justice response. While such policies had the benefit of increased arrest and conviction rates, Section III also explores the critiques of mandatory interventions, analyzing the work of scholars who argue that compulsory engagement with the state is disempowering and potentially dangerous for survivors, particularly those from marginalized communities.

Section III expands upon the critiques detailed in Section II by addressing the specific ways in which the challenges faced by immigrant survivors of domestic violence make them uniquely unable, fearful, or disinclined to engage with law enforcement, as required to obtain a $U$ visa. Battered immigrant women may have limited English skills, preventing them from accessing potentially lifesaving resources that are also gateways to $U$ visa relief. They may distrust or even fear the police due to negative past experiences with law enforcement both in the United States and in their home countries; particularly in the current political climate, they may rationally fear arrest or deportation. Because immigrant survivors of domestic violence are often uniquely isolated, the potential harm of separation from their families or communities that may result from reporting abuse may be disproportionate to the existing harm of the abuse itself. Finally, numerous studies have shown that taking steps to leave an abusive relationship can drastically increase the probability of fatal retaliation from an abusive partner who sees power and control over his victim slipping away. This risk of "separation violence," particularly when access to witness protection is limited, can make working with the police especially dangerous.

Section IV then offers solutions to help alleviate the detrimental effects of the $U$ visa's law enforcement certification requirement. Proposed fixes include eliminating certification; allowing victims at substantial risk of harm as a result of their cooperation to either provide alternative evidence or opt-out from the certification requirement entirely; requiring the federal government to take a more active role in regulating localities' compliance with the $U$ visa program; and offering a pathway for state and local governments to strengthen $U$ visa compliance in their jurisdictions. Drawing from existing humanitarian immigration remedies such as VAWA and the T visa, the suggested revisions to the $U$ visa eligibility criteria seek to minimize compulsory engagement with the state while ensuring the safety of immigrant survivors of domestic violence. In doing so, the $\mathrm{U}$ visa would be able to achieve the aims Congress originally intended, restoring the appropriate balance between protection of victims and benefit to law enforcement. 


\section{THE U VISA}

A comprehensive analysis of the problematic aspects of the U visa first necessitates an understanding of the visa itself. This section will provide the requisite background: eligibility criteria, the benefits the visa provides to recipients, and information about the legislative history surrounding its enactment, including the conditions faced by immigrant survivors of intimate partner violence that compelled the creation of a visa specifically to assist them.

\section{A. Statutory Requirements}

The $U$ visa, or $U$ nonimmigrant status, is a form of immigration relief that is available to an individual who has been a victim of one or more of several enumerated crimes in the United States and has suffered "substantial physical or mental abuse" as a result. ${ }^{2}$ The victim must possess information about the crime and demonstrate that she has been helpful, is currently being helpful, or is likely to be helpful in investigating or prosecuting the criminal activity. ${ }^{3}$ Created as part of the Victims of Trafficking and Violence Prevention Act of 2000, the U visa is available to both undocumented immigrants and those with temporary, or nonimmigrant, legal status. ${ }^{4}$

U visas are only available to 10,000 applicants per year, ${ }^{5}$ but for those 10,000 individuals, the visas provide a path to lawful permanent resident status. First, an

2. 8 U.S.C. $\S 1101(a)(15)(U)(i)(2012)$.

3. Id.

4. For example, if an individual attending a university in the United States on an F-1 student visa or visiting the U.S. on a B-1 visitor visa is the victim of a crime, he or she is eligible to apply for a $U$ visa.

5. 8 U.S.C. $\S 1184(p)$ (2012). The cap applies only to principal applicants, not derivatives on the principal applicant's claim. However, despite this limitation, the demand for $U$ visas has far exceeded their availability. In fiscal year 2014, the cap was reached in December 13, 2013, two and a half months into the fiscal year. In fiscal year 2015, as a result of the backlogged visas from 2014, the cap was reached on October 1, the day the fiscal year began. Although USCIS continues to adjudicate applications once the cap is reached, and grants individuals deferred action as well as work authorization while they wait for their visas to be approved, advocates are concerned about the backlog, which continues to grow. 63,762 applications remained pending at the end of fiscal year 2015. See U.S. Citizenship and IMmigraTion SERvs., Number of I-918 PetiTions for U NONIMMIGRANT STATUS (VICTIMS OF CERTAIN CRIMINAL ACTIVITIES AND FAMILY MEMBERS) BY FISCAL YEAR, QUARTER, AND CASE STATUS 2009-2016 (2016), available at https://www.uscis.gov /sites/default/files/USCIS/Resources/Reports\%20and\%20Studies/Immigration\%20Forms\%20Data/ Victims/1918u_visastatistics_fy2016_qtr2.pdf [https://perma.cc/J7SH-7U26]. This backlog will take six years to clear under current regulations. Only Congress can raise the cap, and while advocates have called for this change, any increase in benefits to immigrants in today's political climate seems unlikely. See, e.g., Advocate for Change: Tell Congress to Raise the U-Visa Cap, IMMIGRANT L. GROUP PC, http://www.ilgrp.com/advocate-for-change-tell-congress-to-raise-the-uvisa-cap/ [https://perma.cc/48BN-EH65]; see also Shah Peerally, Petition to Increase U Visa Cap, IMMIGR. LEGAL, Mar. 25, 2016, http://immigrationlegalblog.com/2016/03/petition-to-increase-uvisa-cap/ [https://perma.cc/7KDC-X23D]. 
individual who has been granted $U$ nonimmigrant status is eligible to receive work authorization. ${ }^{6}$ The work permit and U visa itself are valid for four years, ${ }^{7}$ but after three years, a $U$ nonimmigrant can apply to adjust her status to that of lawful permanent resident, or Green Card holder. ${ }^{8}$

The crimes that make one eligible for a $U$ visa are mostly violent offenses against another person in violation of federal, state or local criminal law. Eligible crimes include domestic violence, rape and sexual assault, stalking, abduction, false imprisonment, manslaughter and murder. ${ }^{9}$ An individual who is the victim of an offense that is similar to any of the enumerated crimes, or the attempt, conspiracy, or solicitation to commit any of the enumerated crimes, may also be $\mathrm{U}$ visa eligible. ${ }^{10}$ Although the list of $U$ visa-qualifying offenses includes almost 30 crimes, a nationwide survey of attorneys and advocates from 220 organizations assisting $U$ visa applicants revealed that nearly 50 percent of applications were based on domestic violence. ${ }^{11}$

To show "helpfulness," per the statute's requirements, an applicant for a $U$ visa must submit a certification form-USCIS Form I-918 ${ }^{12}$ - signed by a federal, state or local law enforcement official, prosecutor, judge, or official at another entity that has criminal investigative jurisdiction over a specific $U$ visa crime (i.e., the Equal Employment Opportunity Commission (EEOC) for workplace crimes or Child .Protective Services for crimes committed against children.). ${ }^{13}$ The official authorized to sign the I-918B form can be either the head of the agency or a "designated certifier" appointed by the agency head. ${ }^{14}$

6. 8 U.S.C. $§ 1184(p)(2012)$.

7. Id.

8. Early Hearing Detection and Intervention Act of 2017, Pub. L. No. 115-71, 131 Stat 1218 (2017) (to be codified at 8 U.S.C. $\S 1255(\mathrm{~m})$ ). In order to qualify for adjustment of status, a U nonimmigrant must demonstrate that they have continuously resided in the United States in U status for the preceding three years, that adjustment is justified "on humanitarian grounds, to ensure family unity, or is otherwise in the public interest," and that they have not "unreasonably refused to provide assistance in a criminal investigation or prosecution." Id.

9. 8 U.S.C. $\$ 1101(a)(15)(U)($ iii) (2012). The full list of offenses that can make the victim eligible for a U visa is: "rape; torture; trafficking; incest; domestic violence; sexual assault; abusive sexual contact; prostitution; sexual exploitation; stalking; female genital mutilation; hostage-taking; peonage; involuntary servitude; slave trade; kidnapping; abduction; unlawful criminal restraint; false imprisonment; blackmail; extortion; manslaughter; murder; felonious assault; witness tampering; obstruction of justice; perjury; [and] fraud in foreign labor contracting." Id.

10. Id.

11. Leslye E. ORloff \& Paige E. Feldman, Nat'L Immigrant Women's Advocacy Project (NIWAP), IMMIGRANT WOMAN PROGRAM, LEGAL MOMENTUM, NATIONAL SURVEY ON TYPES OF CRIMINAL ACTIVITIES EXPERIENCED BY U-VISA RECIPIENTS (2011), available at http://library .niwap.org/wp-content/uploads/2015/National-Survey-on-Types-of-Criminal-ActivitiesUpdated2011.pdf [https://perma.cc/S4AP-TEY2].

12. DEP'T OF HOMELAND SEC., USCIS FORM I-918 (2017), available at https://www.uscis.gov/sites /default/files/files/form/i-918supb.pdf [https://perma.cc/89DQ-76KX].

13. 8 U.S.C. $\$ 1184(\mathrm{p})(2012)$.

14. 8 C.F.R. $\& 214.14(\mathrm{a})(3)(2016)$. 
The dual requirements of victimization and helpfulness differentiate $U$ visa relief from other remedies in immigration law available to survivors of domestic abuse. For example, the Violence Against Women Act provides a path to legal status for survivors of intimate partner violence who are married to either U.S. citizens or lawful permanent residents, but VAWA relief does not require engagement with law enforcement as a prerequisite for status. ${ }^{15}$

Although the $U$ visa certification form is only one part of a $U$ visa application, it is an essential part; the U.S. Citizenship and Immigration Services will not grant $U$ nonimmigrant status without it, a fact that highlights the significant weight placed on assistance to law enforcement. ${ }^{16}$ Several other requirements also underscore the importance of cooperation with law enforcement in the $U$ visa application process. For example, even after the certification form is signed, the victim of a crime has an ongoing responsibility to assist law enforcement. ${ }^{17} \mathrm{~A}$ statement in the Federal Register describes this requirement starkly, noting that "USCIS is excluding from eligibility those alien victims who, after initiating cooperation, refuse to provide continuing assistance when reasonably requested." "Engagement with law enforcement is deemed so critical that a certification can be revoked if an individual ceases to cooperate. ${ }^{19}$ Lastly, when U visa holders seek to adjust their status to that of lawful permanent resident ${ }^{20}$ they must once again demonstrate to USCIS that they have continued to provide all assistance requested by law enforcement. ${ }^{21}$

One function of the law enforcement certification is to serve as a check against fraud, as USCIS "recognize[s] that law enforcement agencies that investigate and prosecute the qualifying criminal activities are in the best position

15. See 8 U.S.C. $\$ 1154$ (a) (2012). The immigration provisions of the Violence Against Women Act are discussed in further detail infra Sections II.B and V.

16. Information for Law Enforcement Agencies and Judges, U.S. CITIZENSHIP AND IMMIGR. SERVS., https://www.uscis.gov/tools/resources/information-law-enforcement-agencies-and-judges [https:// perma.cc/EVJ7-6D58] ("This certification is required evidence for the U visa, and USCIS cannot process the victim's case without it."). In fact, USCIS will not accept a U visa application without the I-918B form. An application packet without a certification form will not even make it past the USCIS mailroom. In addition to the law enforcement certification form, an application for $U$ nonimmigrant status must also include: a statement or declaration from the applicant; evidence of helpfulness and that the applicant was a victim of a crime (e.g., police reports, arrest warrants, sentencing documents); and evidence of substantial harm (e.g., medical or mental health records; photographs of injuries; or affidavits from social service agencies, clergy or witnesses).

17. 8 C.F.R. $\S 214.14($ b) (3) (2016).

18. New Classification for Victims of Criminal Activity; Eligibility for " $U$ " Nonimmigrant Status; Interim Rule, 72 Fed. Reg. 179 (proposed Sept. 17, 2007) (to be codified at 8 C.F.R. $\S \S 103,212$ ) (emphasis added) [hereinafter "U Visa Regulations"].

19. 8 C.F.R. $\$ 214.14(\mathrm{~h})(2)(2016)$.

20. See supra note 8 for a discussion of the requirements for adjustment of status.

21. 8 U.S.C. $\S 1255(\mathrm{~m})(2012)$. 
to determine if a qualifying crime has taken place." ${ }^{22}$ Relatedly, an individual who is deemed to be "culpable for the qualifying criminal activity being investigated or prosecuted is excluded from being recognized as a victim of qualifying criminal activity." 23 Thus, to use a commonly cited example, if a husband and wife colluded to fabricate an incident of domestic violence to report to the police, he would not be eligible for derivative status on her U visa petition..$^{24}$

Victims of a crime can seek a $U$ visa not only for themselves, but also for certain family members, or derivatives. ${ }^{25}$ An applicant who is under 21 years of age can include a spouse, minor children, parents and unmarried siblings under the age of 18 on a petition. An applicant who is 21 years of age or older can include a spouse and minor children.

\section{B. The U Visa and Domestic Violence: A Legislative History}

Although the $U$ visa is available to victims of a wide range of crimes, Congress' intent to connect the visa to the fight against domestic violence, and violence against women more generally, is unmistakable. The most obvious proof is in the titles of the enacting legislation. The $U$ visa was created as part of the Victims of Trafficking and Violence Prevention Act of 2000, a reauthorization of the Violence Against Women Act, and the specific provision detailing $U$ nonimmigrant status was entitled the Battered Immigrant Women Protection Act of 2000 (BIWPA). ${ }^{26}$ Congress listed providing protection to survivors of family and intimate partner violence as a specific purpose of the legislation. ${ }^{27}$

The legislative history is replete with references to and statistics concerning domestic violence generally, and the disproportionate impact that intimate

22. U.S. DEP'T OF HOMELAND SEC., U VISA LAW ENFORCEMENT CERTIFICATION RESOURCE GUIDE FOR FEDERAL, STATE, LOCAL, TRIBAL AND TERRITORIAL LAW ENFORCEMENT 14-15, https://www.dhs .gov/xlibrary/assets/dhs_u_visa_certification_guide.pdf [https://perma.cc/9F6U-L9JG]. The Fraud Detection and National Security Unit (FDNSU) is also alerted to any potentially fraudulent $U$ visa applications.

23. 8 C.F.R. $\$ 214.14($ a)(14)(iii) (2016).

24. It is also worth noting that in addition to the immigration consequences of a false report (i.e., the denial of a visa to both parties as well as any action taken by the FDNSU), potential criminal consequences exist as well. If authorities discover the deception, both parties could be criminally charged with falsifying a police report. Alternatively, if the police believe the fabricated story of domestic violence, the purported abuser could be arrested, jailed, and potentially deported, a series of consequences that outweigh the benefits of derivative $U$ visa status.

25. 8 C.F.R. $\$ 214.14(f)(2016)$.

26. Battered Immigrant Women Protection Act of 2000, Pub. L. No. 106-386 § 1513, 114 Stat. 1464, 1533-37.

27. Id. $\S 1502,114$ Stat. 1518 (Findings and Purposes) ((b) "The purposes of this title are ... (2) to offer protection against domestic violence occurring in family and intimate relationships ...."). 
partner abuse has on immigrant populations. During the Senate hearing on the Victims of Trafficking and Violence Prevention Act, Senator Barbara Mikulski stated that 900,000 women are victims of violence in their homes each year, that "every second, 20 women are battered," and that " 4 women a day are killed by domestic violence." ${ }^{28}$ Similarly, Senator Barbara Boxer read the alarming statistic that "domestic violence is the leading cause of injury to women age 15 to 44 , with nearly one-third of women who are murdered being murdered by a husband or boyfriend." 29

Members of the House highlighted similar statistics. Representative Nita Lowey reported that "experts estimate that 1.5 million women are victims of gender-based violence every year" and the often-quoted figure that "an estimated one in three adult women experiences at least one physical assault by an intimate partner during her lifetime." 30 Representative Tom Udall added that "[m]ore women are injured by domestic violence each year than by automobile accidents and cancer combined. More than one-third of all women using emergency rooms are victims of domestic violence." 31

Beyond the understandable focus on the frequency and lethality of domestic violence in the general U.S. population, supporters of the Battered Immigrant Women Protection Act also highlighted the specific challenges facing non-native born survivors. Senator Boxer explained her support of the Trafficking Victims Protection Act by describing the unique vulnerabilities of immigrant victims, stating: "[w]e also, for the first time, look at battered immigrants .... They need to understand their rights, that their bodies don't belong to anyone else, and they have a right to cry out if they are abused." ${ }^{32}$ At the same hearing, the late Senator Ted Kennedy described the importance of the $U$ visa in equalizing access to justice for all survivors, noting that "Congress enacted the Violence Against Women Act in 1994 to help all victims of domestic violence, regardless of their citizenship." 33

While it is perhaps not surprising that many members of Congress testified about the evils and harms of domestic violence in supporting bills that were a part of the reauthorization of the Violence Against Women Act, the U visa is not technically a gender-specific remedy, nor is it intended to benefit only victims of crimes against women. As explained above, people of all genders may receive $U$ nonimmigrant status, and while the list of qualifying $U$ visa crimes includes many that are traditionally encompassed under the umbrella of violence against

28. 146 Cong. Rec. $\S \S 22053 ; 22054$ (Oct. 11, 2000).

29. Id. at 22050 .

30. 146 Cong. Rec. $\S \S 21312 ; 21342$ (Oct. 6, 2000).

31. Id. at 21345 .

32. 146 Cong. Rec. at 22051.

33. Id. 
women (e.g., rape, sexual exploitation, domestic violence, trafficking, and female genital mutilation), many other covered crimes (e.g., kidnapping, abduction, murder, manslaughter, and felonious assault) are not typically gendered crimes. ${ }^{34}$ However, despite the $U$ visa's broad applicability, it has been associated with domestic violence from its inception. In fact, at the hearing on the Trafficking Victims and Violence Prevention Act of 2000, Representative Sam Gejdenson referred to the $U$ visa as "a new visa for battered immigrant women," cementing a link that continues to this day. ${ }^{35}$

Members of Congress were not incorrect in conceptualizing the $U$ visa as primarily a resource for survivors of gender-based crimes. Much of the rhetoric surrounding the creation and implementation of the visa focused, and continues to focus, on $\mathrm{U}$ nonimmigrant status as a remedy for victims of domestic abuse. For example, when the U visa regulations were promulgated in 2007, the Federal Register notice stated, "the purpose of the U nonimmigrant classification is to strengthen the ability of law enforcement agencies to investigate and prosecute such crimes as domestic violence, sexual assault, and trafficking in persons, while offering protection to alien crime victims in keeping with the humanitarian interests of the United States." ${ }^{36}$ Non-gender-based crimes covered under the U visa are often an afterthought; the Register describes the list of qualifying crimes as representing "the myriad types of behavior that can constitute domestic violence, sexual abuse, or trafficking, or are crimes of which vulnerable immigrants are often targeted as victims." ${ }^{37}$

Further linking the $U$ visa to gender-based violence, the history of related advocacy reveals that many considered the $U$ visa a way to close a loophole for those who were otherwise ineligible for previously enacted immigration remedies under the 1994 Violence Against Women Act. The Violent Crime Control and Law Enforcement Act of 1994 operationalized VAWA, creating a process whereby an abused spouse of a U.S. citizen or Lawful Permanent Resident, who but-for the abuse would be able to obtain lawful permanent residency through that spouse, could "self-petition" for immigration status. ${ }^{38}$ While a significant benefit for many, VAWA self-petitioning left unprotected women who were not married to their abusers or those who were married to individuals who were either undocumented or had some form of temporary immigration status (e.g., a student or employment-based visa). When the Victims of Trafficking and Violence Prevention Act was enacted in 2000, one of the

\footnotetext{
34. 8 U.S.C. $\S 1101(a)(15)(U)($ iii) (2012).

35. 146 Cong. Rec. $\$ 9029$ (Oct. 6, 2000).

36. U Visa Regulations, supra note 18 (emphasis added).

37. Id.

38. Violent Crime Control and Law Enforcement Act of 1994, H.R. 3355, Pub. L. No. 103-322, 108 Stat. 1796 (1994).
} 
"Findings and Purposes" regarding the U visa references this intention, as it states:

there are several groups of battered immigrant women and children who do not have access to the immigration protections of the Violence Against Women Act of 1994 which means that their abusers are virtually immune from prosecution because their victims can be deported as a result of action by their abusers and the Immigration and Naturalization Service cannot offer them protection no matter how compelling their case is under existing law. ${ }^{39}$

The $\mathrm{U}$ visa has from its origination been seen and likely even intended as a mechanism to protect survivors of gender-based violence, specifically, intimate partner or sexual violence. The need for such protections was and remains clear, as will be demonstrated below.

\section{Domestic Violence and Immigrant Women: Prevalence, Risk, and Lethality}

Although domestic violence can impact women regardless of their racial group, socio-economic status, or country of origin, immigrant women are uniquely vulnerable to intra-family violence and are more likely to face domestic abuse than members of the general population. The reasons for immigrant women's susceptibility to intimate partner violence are broad and varied and have been studied extensively by scholars in legal and other fields. ${ }^{40} \mathrm{~A}$ full examination of the complex issues underlying the challenges faced by non-native born survivors of domestic violence is beyond the scope of this article. However, as Congressman Lamar Smith succinctly put it in his opening statement during the hearing on the Battered Immigrant Women Protection Act of 2000 before the House Subcommittee on Immigration and Claims, "[d]omestic abuse is a major and disturbing problem in this country and throughout the world. When the abused is an alien, the problem becomes even more complex." ${ }^{, 41}$ Generally, the interplay and intersection of immigration laws, language barriers, social and

39. Victims of Trafficking and Violence Protection Act of 2000, 114 Stat. $1518 \S 1502(\mathrm{a})(3)$.

40. See, e.g., Daniel Epstein, Romance Is Dead: Mail Order Brides as Surrogate Corpses, 17 BUFF. J. GENDER, L. \& SOC. POL'y 61, 77-78 (2009); Felicia E. Franco, Unconditional Safety for Conditional Immigrant Women, 11 BERKELEY WOMEN's L.J. 99, 123-27 (1996); Jacqueline P. Hand \& David C. Koelsch, Shared Experiences, Divergent Outcomes: American Indian and Immigrant Victims of Domestic Violence, 25 WIS. J.L. GENDER \& SOC'Y 185, 186-195 (2010); TienLi Loke, Note, Trapped in Domestic Violence: The Impact of United States Immigration Laws on Battered Immigrant Women, 6 B.U. PUB. INT. L.J. 589, 589 (1997); Mariela Olivares, Battered by Law: The Political Subordination of Immigrant Women, 64 AM. U. L. REV. 231, 238 (2014).

41. Battered Immigrant Women Protection Act of 1999: Hearing on H.R. 3083 Before the Subcommittee on Immigration and Claims of the H. Comm. on the Judiciary, 106th Cong. 1 (2000) (statement of Rep. Lamar Smith, Chairman, H. Comm. on the Judiciary). 
familial isolation, financial constraints, and cultural differences leave many immigrant women vulnerable to exploitation, with few options to remedy their situations.

Violence against women is one of the most common forms of victimization experienced by immigrants. ${ }^{42}$ Experts have noted that "between 34 and 49.8 percent of immigrant women in this country experience domestic violence in their lifetimes. ${ }^{\circ 3}$ A contemporaneous study of Latina, South Asian and Korean immigrants revealed that " $30 \%$ to $50 \%$ had been sexually or physically victimized by a male intimate partner." ${ }^{\text {"44 }}$ Another study found that foreign-born Latinas were "twice as likely as their US born counterparts to have been subjected to recent IPSV [intimate partner sexual violence]." ${ }^{45}$ The incidence of intimate partner abuse in immigrant communities is so significant, that experts have labeled it a "pandemic."46 This is not to suggest, however, that immigrants are more likely to perpetrate abuse, but instead that "the experiences of immigrant women in domestic violence situations are often exacerbated by their specific position as immigrants. ${ }^{.47}$ Put another way, the immigrant experience may itself be isolated as a source of increased abuse; in one study, 48 percent of Latinas reported that the violence they had faced in their home countries increased upon their immigration to the United States. ${ }^{48}$

Not only do immigrant women experience domestic abuse more frequently than their native-born counterparts, they also face an increased level of danger from the violence they suffer. The confluence of immigration-related, physical and emotional abuse in a relationship "appears to be a predictor of the lethality of abuse. ${ }^{\$ 49}$ A review of medical examiner records in New York City led

42. Robert C. DAVIS \& EdNA EREZ, NAT'L INST. OF JUSTICE, OfFice OF Justice Programs, U.S. DEP'T OF JUSTICE, IMMIGRANT POPULATIONS AS VICTIMS: TOWARD A MULTICULTURAL CRIMINAL JUSTICE SYSTEM (1998), available at http://www.ncdsv.org/images/NIJ_ImmigrantPopulationsAs VictimsTowardAmulticulturalCJsystem_5-1998.pdf [https://perma.cc/5VJL-JVH4].

43. Battered Immigrant Women Protection Act of 1999: Hearing on H.R. 3083 Before the Subcommittee on Immigration and Claims of the H. Comm. on the Judiciary, 106th Cong. 58 (2000) (statement of Leslye Orloff, Director, Immigrant Women Program, NOW Legal Defense and Education Fund).

44. Anita Raj \& Jay Silverman, The Roles of Culture, Context, and Legal Immigrant Status on Intimate Partner Violence, 8 VIOLENCE AGAINST WOMEN 367, 367 (2002).

45. Courtenay E. Cavanaugh et al, Intimate Partner Sexual Violence: A Comparison of Foreign-Versus US-Born Physically Abused Latinas, 91 J. URBAN HEALTH 1, 130 (2013).

46. Anita Raj \& Jay Silverman, supra note 44, at 369.

47. Cecilia Menjivar \& Olivia Salcido, Immigrant Women and Domestic Violence: Common Experiences in Different Countries, 16 GENDER \& SOC'Y 898, 902 (2002). The authors explain that "immigrant-specific conditions are superimposed on other systems of oppression, such as class, race, and ethnicity, to further increase immigrant women's vulnerability to domestic violence." Id.

48. Chris Hogeland \& Karen Rosen, COAL. FOR IMMigrant AND REFugee RightS AND SERVS., DREAMS LOST, DREAMS FOUND: UNDOCUMENTED WOMEN IN THE LAND OF OPPORTUNITY (1990), available at http://library.niwap.org/wp-content/uploads/2015/LMM-Rsch-DreamsLostDreams Found.pdf [https://perma.cc/HV55-VRSM].

49. Statement of Leslye Orloff, supra note 43. 
researchers to conclude that foreign-born Latina women were at "more than two and a half times greater risk of intimate partner femicide, as compared with nonforeign-born, non-Latina women." 50

Lastly, and significantly to the drafters and legislative proponents of the $U$ visa, immigrant survivors of crime-including domestic violence-are often reluctant to seek assistance from law enforcement. ${ }^{51}$ Women with stable immigration status have been found to be two times more likely than undocumented women to contact the police to report domestic abuse..$^{52}$ Explanations for immigrant victims' hesitancy and fear of engagement with police are detailed in Section III below, but significantly here, the lack of trust in law enforcement results in increased harm and risk to immigrant women who are victims of domestic abuse.

The $U$ visa sought to protect victims by removing a significant barrier to reporting - fear of deportation-in providing a pathway for immigrant victims who cooperate with law enforcement to regularize their status. However, as Section III details, requiring interaction with authorities as a condition of receiving the $U$ visa has had many unintended consequences, and like the mandatory interventions that preceded it-which will be addressed in the next Section-the most vulnerable victims are often left without necessary protections, or paradoxically, placed in increasingly precarious situations as a result of their involvement with law enforcement.

\section{MANDATORY INTERVENTIONS}

The history that paved the way for the U visa's law enforcement cooperation requirement dates as far back as the 19th century. After ignoring and often condoning domestic violence for decades, political, cultural, and legal forces swung the pendulum from official neglect to mandating legal intervention in the lives of survivors of intimate partner violence. This Section will provide an overview of that historical context, describe how interventions-including mandatory arrest and no drop prosecution - operate today, and detail the benefits as well as the drawbacks and feminist legal critiques of such approaches.

50. Victoria Frye et al., Femicide in New York City: 1990 to 1999, 9 HOMICIDE STUd.: AN INTERdisC. \& INT'L J. 204, 217 (2005).

51. See, e.g., InT'L Ass'N OF Chiefs of POLICE, POlice Chiefs Guide to IMMigration Issues 11 (2007), http://www.theiacp.org/Portals/0/pdfs/Publications/PoliceChiefsGuidetolmmigration.pdf [https://perma.cc/28LD-2ZSA] [hereinafter "IACP"] ("In particular [undocumented] immigrants are often afraid to report crime to local authorities, making them easy targets for those with criminal intentions.").

52. Nawal H. Ammar et al., Calls to Police and Police Response: A Case Study of Latina Immigrant Women in the USA, 7 INT'L J. OF POLICE SCI. \& MGMT. 230, 236 (2005). 


\section{A. A Legacy of Indifference}

The $U$ visa is not unique in its effort to aid victims of domestic violence by requiring interaction and cooperation with law enforcement. Mandatory interventions have a long history in the United States, the roots of which date back centuries and exist as a reaction to society's disregard for domestic violence. And although the $\mathrm{U}$ visa may not technically mandate cooperation with law enforcement in the same way as mandatory arrest and no drop prosecution policies described below-after all, victims retain the choice of whether to seek the $U$ visa (and engage with law enforcement) or to remain in the shadows without lawful immigration status - it can certainly be described as a coerced choice that is in the spirit of the mandatory interventions that preceded it.

For centuries, the state refused to intervene in situations of spousal abuse. English common law prescribed that a husband was permitted to beat his wife as long as his "rod [was] not thicker than his thumb." 53 In 1873, the Supreme Court of North Carolina opined on the appropriate response to domestic violence, stating that "[i]f no permanent injury has been inflicted, nor malice, cruelty nor dangerous violence shown by the husband, it is better to draw the curtain, shut out the public gaze, and leave the parties to forget and forgive." 54

If a woman called the police to seek protection from her partner's attacks, such calls were regularly ignored. And if officers did arrive, their responses often did not provide a victim of domestic violence the safety and security she sought. Law enforcement officials routinely blamed victims for provoking the attacks they had suffered, admonishing them to be "better wives" in order to prevent future violence. ${ }^{55}$ Some officers even suggested that victims must have enjoyed the beatings they were subjected to, or at least did not mind them, because they had not taken action to leave the relationship. ${ }^{56}$ Victims in traditionally underserved communities faced heightened levels of repudiation. As Professor Donna Coker explains, "[p]olice often believe that violence is an unremarkable event in the households of poor people of color and that police intervention is therefore likely to be ineffective or unnecessary." 57 A study of the Phoenix Police Department revealed officers' beliefs that 'arrests were a waste of time and

53. U.S. COMM'N ON CIVIL RIGHTS, UNDER THE RULE OF THUMB: BATTERED WOMEN AND THE ADMINISTRATION OF JUSTICE 2 (1982), available at https://www.law.umaryland.edu/marshall/usccr /documents/cr12w8410.pdf [https://perma.cc/G76J-ZYYQ].

54. State v. Oliver, 70 N.C. 60, 61-62 (1874).

55. Susan Schechter, WOMEN and Male VIOLENCE: The Visions and STRuggles of the BATTERED WOMEN'S MOVEMENT 58 (1982).

56. Id.

57. Donna K. Coker, Shifting Power for Battered Women: Law, Material Resources, and Poor Women of Color, 33 U.C. DAVIS L. REV. 1009, 1033 (2000). 
meaningless" in certain immigrant communities and low-income neighborhoods "because violence is a way of life for them."

As shocking as these statements and attitudes are, they did not represent the actions of a few rogue officers, nor were they isolated incidents. Instead, such responses were institutionalized in public policy and law enforcement training, as "[t]hroughout the 1970 s and early 1980 s, officers believed and were taught that domestic violence was a private matter, ill suited to public intervention." In this belief, police officers did not differ significantly from the general public, where deference to familial privacy-deeply rooted in historical conceptions of masculinity and gender roles-was firmly entrenched. Of course, what follows from a conception of the sanctity of the marital home is the perceived impropriety not only of interference in the affairs of a married couple, but of analysis or inquiry about what occurs between a husband and wife, even in cases of suspected abuse or violence. Thus, officers responding to a report of domestic violence were empowered to act upon their well-ingrained and likely unchallenged beliefs that domestic violence is justified, or that law enforcement's role is to act in order to preserve the family unit, as opposed to providing protection to the victim. ${ }^{60}$

Eventually, norms of non-interference were codified in law enforcement policies. For example, the Oakland, California Police Department's 1975 "Training Bulletin on Techniques of Dispute Intervention" details a policy of non-arrest in situations of domestic violence. ${ }^{61}$ The bulletin describes a police officer responding to a report of intimate-partner abuse as "a mediator and peacemaker" as opposed to an "enforcer of the law." 62 Ultimately, the Oakland Police Department advanced an official policy that arrests in cases of domestic violence "shall be avoided." ${ }^{63}$ In order to effectuate this goal, officers were instructed to actively discourage survivors from pressing charges by emphasizing the negative "ramifications of such action (e.g., loss of wages, bail procedures, court appearances) and [were taught to] encourage the parties to reason with each other." 64

\footnotetext{
58. Kathleen J. Ferraro, Policing Battered Women, 36 SOC. PROBS. 61, 67 (1989).

59. Joan Zorza, The Criminal Law of Misdemeanor Domestic Violence; 1970-1990, 83 J. CRIM. L. \& CRIMINOLOGY 46, 47 (1992) (emphasis added).

60. Daniel G. Saunders, The Tendency to Arrest Victims of Domestic Violence: A Preliminary Analysis of Officer Characteristics, 10 J. INTERPERSONAL VIOLENCE 147, 155-56 (1995).

61. Del MARTIN, BATTERED WIVES 92-94 (1976).

62. Id.

63. $I d$.

64. Id. The Oakland Police Department was certainly not alone in its approach. The Police Training Academy in Michigan also directed officers to "avoid arrest if possible," and suggested that this could be accomplished by appealing "to their [complainant's] vanity." Zorza, supra note 59 , at 49 . And as in California, police in Michigan were trained to discourage reporting by detailing the
} 
Police indifference was only the first of many challenges for women facing abuse who sought aid from the state. Survivors who managed to have their perpetrators arrested found that the sentences imposed after a conviction did not match the seriousness of the crime or the harm they had experienced. ${ }^{65}$ Official policies and unofficial practices of ignoring or justifying domestic abuse reflected the realities of society at the time. As Representative Louise Slaughter eloquently stated in her testimony in support of the Victims of Trafficking and Violence Prevention Act of 2000, "[w]omen knew only too well that we were in the midst of a deadly epidemic, but the culture of silence that surrounded the issue made it difficult for them to speak out or to get help." ${ }^{66}$ Intimate partner violence was "trivialized by law enforcement, by the judicial system, by health care providers and sometimes even by friends, family or neighbors," leaving survivors isolated and unable to escape abuse. 67

\section{B. Revolution in the 1960s and 1970 s}

The feminist movement of the 1960s and 1970s led to many advances in the fight to improve public response to and support for victims of intimate partner violence. Efforts to provide safety and basic services to women, such as "safe houses and shelters, were soon followed by advocacy for effective civil and criminal justice interventions on behalf of battered women." ${ }^{\prime 68}$ Many of these interventions were enacted in direct response to law enforcement's unwillingness to intervene in "family disputes" and sought to provide enhanced legal protections and assistance to survivors of domestic violence. ${ }^{69}$

numerous steps involved in obtaining a warrant, with a focus on the length of time and associated costs. Id.

65. See Cheryl Hanna, The Paradox of Hope: The Crime and Punishment of Domestic Violence, $39 \mathrm{WM}$. \& MARY L. REV. 1505, 1521-24 (1998).

66. 146 Cong. Rec. 9029 (2000).

67. Id.

68. Leigh Goodmark, Law Is the Answer? Do We Know That for Sure? Questioning the Efficacy of Legal Interventions for Battered Women, 23 ST. LouIS U. PUB. L. REV. 7, 9 (2004).

69. Scholars have critiqued the emphasis that these early feminist advocates placed on criminalization of domestic violence, while overlooking or deemphasizing broader societal constructs that condoned and failed to protect or support survivors of violence. See, e.g., Aya Gruber, The Feminist War on Crime, 92 lowA L. REV. 741, 794 (2007) (discussing the 1984 Final Report of the Attorney General's Task Force on Family Violence, wherein conservative politicians characterize the problem of domestic violence "in a distinctly criminal rather than social or economic context."); Holly Maguigan, Wading into Professor Schneider's Murky Middle Ground Between Acceptance and Rejection of Criminal Justice Responses to Domestic Violence, 11 AM. U. J. GENDER SOC. POL'Y \& L. 427 (2003); Emily J. Sack, Battered Women and the State: The Struggle for the Future of Domestic Violence Policy, 2004 WIS. L. REV. 1657 (2004); Elizabeth M. Schneider et al., Battered Women \& Feminist Lawmaking: Author Meets Readers, Elizabeth M. Schneider, Christine Harrington, Sally Engle Merry, Renée Rökens, \& Marianne Wesson, 10 J.L. \& POL'Y 313, 359 (2002) (Elizabeth Schneider notes that focusing on criminalization suggests that domestic violence occurs in isolation and is "not linked to the larger issues of women's economic situation, gender 
Because advocates believed that police were at best indifferent and at worst hostile to the problem of domestic abuse, one of their primary goals was to eliminate officers' exercise of discretion when responding to domestic violence calls. ${ }^{70}$ In doing so, they hoped that police and prosecutors would treat domestic violence like any other crime and that the assault of an intimate partner would be considered as serious of an offense as an assault on a stranger.

A study conducted in Minneapolis, Minnesota helped quickly advance the cause of mandatory legal interventions in cases of intimate partner violence. ${ }^{71}$ In an effort to test the effectiveness of potential responses to domestic violence by the legal system, police were instructed to either arrest, counsel, or separate offenders from their partners. The study's authors then tracked whether any of the over 300 perpetrators who participated in the experiment re-offended within six months of arrest in order to test the relationship between recidivism and police intervention in incidents of domestic violence. The unequivocal conclusion was that arrest was the most effective means-nearly twice as effective as other actions - of reducing the likelihood of further domestic abuse. $^{72}$

In light of these findings, the National Institute of Justice commissioned studies in six additional cities in an effort to replicate and test the Minneapolis results. ${ }^{73}$ The outcomes of those studies were mixed. Some showed that arrest deterred future violence, but others showed no deterrent effect. Significantly, some showed that arrest led to increases in future violence. ${ }^{74}$ However, despite the lack of certainty surrounding the effectiveness of arrest in preventing domestic violence, local and federal policy makers latched onto the first study, the Minnesota results, and began instituting a series of mandatory legal interventions in cases of domestic abuse. As criminal justice scholar Steven Schulhofer explains,

socialization, sex segregation, reproduction, and women's subjugation within the family."); Stephen J. Schulhofer, The Feminist Challenge in Criminal Law, 143 U. PA. L. REV. 2151 (1995).

70. See Maguigan, supra note 69 , at 430 (" $[\mathrm{t}]$ he desire to remove discretion from police and prosecutors stems from a sense of the historic inadequacy of their response to domestic violence . ...").

71. Lawrence W. Sherman \& Richard A. Berk, The Specific Deterrent Effects of Arrest for Domestic Assault, 49 AM. SOC. REV. 261 (1984).

72. Id.

73. Studies were conducted in Omaha, Nebraska; Charlotte, North Carolina; Milwaukee, Wisconsin; Miami-Dade County, Florida; Colorado Springs, Colorado; and Atlanta, Georgia. ARLENE WEISZ, APPLIED RESEARCH FORUM, NAT'L ELEC. NETWORK ON VIOLENCE AGAINST WOMEN, SPOUSE ASSAULT REPLICATION PROGRAM: STUDIES OF EFFECTS OF ARREST ON DOMESTIC VIOLENCE (Nov. 2001), available at $\mathrm{https} / /$ vawnet.org/sites/default/files/materials/files/2016-09/AR_Arrest.pdf [https://perma.cc/F9R5-H89X].

74. Id. See also J. David Hirschel \& Ira W. Hutchison, Realities and Implications of the Charlotte Spousal Abuse Experiment, in Do ARRESTS AND RESTRAINING ORDERS WORK? 54-55 (Eve S. Buzawa \& Carl G. Buzawa eds., 1996). 
The tentative Minneapolis study and its recommendations for a more punitive approach received widespread attention and an immediately favorable reception, but public officials and the media have either attacked or ignored the more thorough studies that suggest the opposite conclusion. Theoretical and ideological commitments to punitive strategies and to a rights-oriented response to aggression seem to dominate any concern for designing operational programs which actually help abused women. ${ }^{75}$

Along with the Minneapolis study, the political and legal changes of the 1960s and 70 s ushered in a new era of response to intimate partner violence in the United States. In this re-envisioned framework, law enforcement intervention was seen as a critical, even necessary, element of combatting domestic abuse and new laws implementing this vision were soon enacted.

\section{Modern Approaches}

\section{Mandatory Arrest}

Mandatory arrest policies were the first and most widely utilized legal interventions in cases of domestic abuse. The policies compel officers who respond to a domestic violence call to effectuate an arrest once probable cause has been established. Such a policy is unique to the area of domestic violence; police retain discretion over whether to make an arrest for any other class of offense. ${ }^{76}$ Because an arrest is required, officers can no longer make subjective determinations-based on seriousness of injury, attitude or demeanor of the victim, their own biases, etc. - of whether to take the perpetrator into custody.

Pro-arrest policies are similar to mandatory policies in that they encourage, but ultimately do not require arrest. They are a middle ground, allowing officers "to consider the unique situation of the batterer and the victim and to assess whether an arrest is appropriate." 77

The first mandatory arrest policy was instituted in Oregon in $1989 .{ }^{78}$ Since that time, all jurisdictions in the United States have followed suit and enacted similar policies, largely due to enticements built into the 1994 Violence Against Women Act. VAWA, which was enacted as part of the 1994 Crime Act, made

75. Stephen J. Schulhofer, The Feminist Challenge in Criminal Law, 143 U. PA. L. REv. 2151, 2164 (1995).

76. See Kevin Walsh, The Mandatory Arrest Law: Police Reaction, 16 PACE L. REV. 97, 98 (1995).

77. Donna M. Welch, Mandatory Arrest of Domestic Abusers: Panacea or Perpetuation of the Problem of Abuse?, 43 DEPAUL L. REV. 1133, 1160 (1994).

78. Or. Rev. Stat. $\S 133.055(2)(2015)$. See also Zorza, supra note 59, at 63 (discussing the enactment of Oregon's mandatory statute). 
available substantial funding for law enforcement and prosecution efforts to combat domestic abuse. ${ }^{79}$ The Department of Justice's Office on Violence Against Women, created to implement many of VAWA's mandates, has awarded over $\$ 6$ billion in grants since its inception in 1995 to support organizations and programs seeking to prevent domestic and sexual violence and aid its victims. ${ }^{80}$ The vast majority of funds have gone to criminal justice (as opposed to social service) agencies. ${ }^{81}$ These resources have "prompted police and prosecutors to redouble their efforts to hold batterers criminally accountable. ${ }^{.82}$

The Violence Against Women Act led directly to the proliferation of mandatory arrest policies across the United States by conditioning eligibility for millions of dollars in funding to state and local police departments on the requirement that states certify that they had promulgated pro or mandatory arrest policies. Not surprisingly, all jurisdictions quickly enacted such policies. These actions cemented the connection between domestic violence and criminal justice interventions, paving the way for analogous initiatives in new areas of the law, such as the $U$ visa.

\section{Mandatory, or No Drop, Prosecution}

Mandatory, or "no drop," prosecution is a natural extension of mandatory arrest policies into the court system. Under such policies, prosecutors are not permitted to dismiss criminal charges in a domestic violence case, even if the victim does not want to cooperate with the prosecution or see it proceed.

No drop policies benefit prosecutors by creating certainty and clarity. The former chief of the Domestic Violence Unit in the D.C. U.S. Attorney's Office explained that he supported no drop in his jurisdiction "because he found it impossible to distinguish between victims who genuinely wished to drop charges

79. In describing the successes of VAWA several years later at a hearing on the 2000 reauthorization of the law, Representative Chris Shays focused squarely on the significance of the criminal justice system in combatting violence against women, stating that "[s]ince it was signed into law in 1994, the Violence Against Women Act has strengthened criminal laws and provided funding to enhance their enforcement. It has also provided a foundation for a successful long-term criminal justice effort to end violence against women." 146 Cong. Rec. 8086, 8099 (Sept. 26, 2000).

80. Office of Violence Against Women: About the Office, U.S. DEP'T OF JUST., https://www.justice.gov /ovw/about-office [https://perma.cc/LVT8-UZ4J] (last updated June 16, 2017).

81. Jill T. Messing et al., The State of Intimate Partner Violence Intervention: Progress and Continuing Challenges, 60 SOC. WORK 4 (2015). The study notes that in 1994, 62 percent of funds appropriated under VAWA went to criminal justice agencies, and 38 percent to social services. By 2013, VAWA authorizations had doubled, but the proportion of funding for social services "had decreased to approximately 15 percent of the total, resulting in a smaller dollar amount appropriated for social services in 2013 than in 1994." Id.

82. Goodmark, Law Is the Answer?, supra note 68, at 9. Increased resources also led to a variety of legal developments such as "civil protection orders and domestic violence provisions in custody and visitation statutes, increased criminal penalties for domestic violence, and the adoption of mandatory arrest and no-drop policies." Id. 
and those who were being coerced" by their abusers. ${ }^{83}$ Prosecutors feared that allowing victims to control whether a case moved forward "ceded to perpetrators an enormous degree of control over the criminal justice process. All a batterer had to do was coerce his victim-through violence or threats of violence-into asking the prosecutor to drop the charges; once she did so, the risk of incarceration instantly vanished." $" 84$

This D.C. prosecutor's support for no drop policies presumes that a victim's decision to drop charges can never be a rational or non-coerced choice, which, as will be discussed in Section III below, is a flawed assumption. It also rests on the premise that no drop policies are the only, or even the best, way to address threats or coercion of victims by abusers. ${ }^{85}$ Nevertheless, instituting a policy prohibiting prosecutors from ceding to the wishes of victims removes ambiguity from the process and secures more convictions, often aligning with the overarching policy goals of prosecutors' offices nationwide. ${ }^{86}$

\section{Benefits and Critiques}

The benefits of mandatory interventions are both real (e.g., the aforementioned increased conviction rate for domestic abusers) and symbolic. Requiring officers to arrest perpetrators of domestic violence deprives law enforcement of the discretion to not treat intimate partner violence as a crime. Arguably, a regime under which police officers arrest batterers by default is an improvement over the days when domestic violence was ignored or even condoned by the state.

Mandatory interventions can also have positive impacts for survivors of domestic violence. Police intervention can literally save a survivor's life. In addition, interaction with law enforcement often serves as a gateway to access additional social and legal services, such as immigration assistance, which can provide victims with the safety and justice they desperately need and deserve. There may be psychological benefits as well; a victim "who takes the witness

83. Deborah Epstein, Redefining the State's Response to Domestic Violence: Past Victories and Future Challenges, 1 GEO. J. GENDER \& L. 127, 137-38 (1999).

84. Id. at 134 .

85. It is noteworthy that while witness intimidation is a significant concern in the area of criminal prosecution of domestic violence, as discussed infra Sections III.B.3.ii and IV, no exceptions currently exist for $U$ visa applicants who either do not report or cease cooperating with law enforcement as a result of threats from an abuser.

86. See BARBARA E. SMITH \& ROBERT C. DAVIS, AMERICAN BAR ASS'N, AN EVALUATION OF EFFORTS TO IMPLEMENT NO-DROP POLICIES: TWo CENTRAL VALUES IN CONFLICT 9 (2004), available at https://www.ncjrs.gov/pdffiles1/nij/199719.pdf [https://perma.cc/N9U9-42EW]; see also Laurie S. Kohn, The Justice System and Domestic Violence: Engaging the Case but Divorcing the Victim, 32 N.Y.U. REV. L. \& SOC. CHANGE 191, 219 (2008) ("... the no-drop prosecution policy[] has dramatically increased the raw number of annual prosecutions."). 
stand and testifies truthfully could feel empowered because in standing up to her abuser she is transformed into a survivor."

Moreover, both mandatory arrest and no drop prosecution policies send a symbolic message that intra-family violence will not be tolerated. Compelling the arrest and prosecution of those who commit domestic abuse raises the recognized gravity of violence against one's spouse or partner to the gravity of violence against a stranger, a parity that has long been the goal of advocates. As Professor Deborah Epstein states, "[t]he concept of treating family abuse 'like any other crime' is finally within reach." 88

Lastly, as Professor Elizabeth Schneider has noted, mandatory arrest "further[s] the proper role of state and prosecutor in domestic violence cases ... [wherein the] role of the prosecutor is to represent the people of the state ... [and] the decision whether to prosecute a crime should not rest with the victims but with the state. ${ }^{" 89}$ In conceiving the beneficiary of prosecution as the statethe public interest, community, or society as a whole as opposed to the victim herself-the advantage of mandatory interventions can be more clearly understood.

However, despite these stated benefits, many scholars and advocates argue that the pendulum has swung too far and that the deprivation of choice inherent in mandatory legal interventions can be extraordinarily harmful to survivors of domestic violence.

First, some survivors may not want to be involved with a criminal justice system that they view with suspicion or distrust. This is particularly true for women in minority or marginalized communities, as "race, class, sexual orientation, immigration status, and other identities may have [a profound impact] on women's decisions to invoke formal systems. "990 If a woman's previous calls to police have gone unanswered, if officers who responded in the past did not treat her or her family members with respect or kindness, she may be disinclined to reach out for help again. If an immigrant woman views local police as agents of a federal immigration system that seeks her deportation, her willingness to engage with that system will obviously be curtailed. ${ }^{91}$ And if a Black woman believes that reporting domestic violence will confirm biases of

87. Njeri M. Rutledge, Turning a Blind Eye: Perjury in Domestic Violence Cases, 39 N.M. L. REV. 149, 154 (2009).

88. Epstein, supra note 83, at 136.

89. ELIZABETH M. SCHNEIDER, BATTERED WOMEN AND FEMINIST LAWMAKING 185 (2000).

90. Leigh Goodmark, Autonomy Feminism: An Anti-Essentialist Critique of Mandatory Interventions in Domestic Violence Cases, 37 FLA. ST. U. L. REV. 1, 37 (2009).

91. See Angelica S. Reina et al., "He Said They'd Deport Me": Factors Influencing Domestic Violence Help-Seeking Practices Among Latina Immigrants, 29 J. INTERPERSONAL VIOLENCE 593, 600-01 (2014). The study found that undocumented survivors of domestic violence, as well as those with unstable immigration status, "believed that reporting the abuse or seeking help could have led to their deportation," which kept them from seeking help. Id. 
law enforcement towards African American men or will lead to the incarceration of another Black male, she may decide that the needs of her community override her individual safety. ${ }^{92}$

It is difficult to disentangle issues of race, gender, poverty, sexual orientation, and class from conversations about domestic violence and law enforcement, as women's intersectional identities significantly impact their attitudes toward engagement with the state. Ultimately, we must remember that “. . . for many battered women[,] criminal prosecution is deeply problematic . . . [A]ctivists and legal reformers continue to raise questions concerning criminalization, reflecting tensions around issues involving women's autonomy, poor women, and women of color ....."93 As such, a blanket policy that forces all survivors to engage with law enforcement discounts their individualized experiences and desires.

Regardless of survivors' feelings about the efficacy of law enforcement, they may still make an informed choice to not seek outside intervention in their relationship or to discontinue engagement that either they initiated or someone else initiated on their behalf (e.g., after a neighbor calls the police to report a disturbance).$^{94} \mathrm{~A}$ decision to avoid police involvement is often a rational calculation, "made based on past experiences and with intimate knowledge of their partners, their resources, their political views, their family concerns-in short, based on the lives that they seek to fashion." "F5 example, some victims of abuse simply want the violence they are facing to stop; they do not want to leave their spouse or partner or see them punished. ${ }^{96}$

92. Studies have shown that men of color have borne the brunt of harsher domestic violence laws. In Milwaukee County, Wisconsin, for example, although African Americans represented only $24 \%$ of the total population, they constituted $66 \%$ of domestic violence arrests. Sarah M. Buel, The Pedagogy of Domestic Violence Law: Situating Domestic Violence Work in Law Schools, Adding the Lenses of Race and Class, 11 AM. U. J. GENDER SOC. POL'Y \& L. 309, 319 (2002). See also Donna Coker, supra note 57, at 1034-35 (noting that "disproportionate numbers of African American and somewhat lower but still disproportionately high numbers of Latina/os are the subject of criminal justice intervention in domestic violence cases").

93. SCHNEIDER, supra note 89, at 196.

94. Statistics confirm that survivors of intimate partner violence are often disinclined to reach out to law enforcement. Data collected and analyzed by the Department of Justice indicates that nearly half of the incidents of intimate partner violence experienced by women are not reported to the police. U.S. DEP'T OF JUSTICE, CRIMINAL VICTIMIZATION, 20167 (2017), available at https://www.bjs.gov /content/pub/pdf/cv16.pdf [https://perma.cc/GPW2-2RBP]. And if cases proceed to prosecution, studies have shown that between 60 to 80 percent of victims drop charges, recant, or otherwise fail to participate in domestic violence criminal cases. EVE S. BUZAWA \& CARL G. BUZAWA, DOMESTIC VIOLENCE: THE CRIMINAL JUSTICE RESPONSE 87 (1990).

95. Goodmark, Autonomy Feminism, supra note 90, at 38.

96. Richard B. Felson et al., Reasons for Reporting and Not Reporting Domestic Violence to the Police, 40 CRIMINOLOGY 617,619 (2002). This concern is particularly implicated if the punishment faced by an abuser is disproportionate to the offense (e.g., deportation for a relatively minor physical assault). 
A victim is "in a better position to choose [how to protect herself], as she knows best what her partner is capable of and what is likely to occur from the separation." ${ }^{\text {97 }}$ A member of the staff of Genesis Women's Shelter in Dallas, Texas colorfully explains this phenomenon by inquiring about the best place to stand when in a room with a fire-breathing dragon. Upon reflection, most respond that the safest place is right next to, or even under, the dragon, highlighting the fact that in order to survive, victims may be forced to align themselves with their abuser. ${ }^{98}$ For many people facing domestic violence, separation from an abuser is not the ultimate goal, due to myriad complex and interrelated reasons such as economic needs, emotional, cultural or familial ties, or safety concerns. For these victims, the arrest and prosecution of a spouse or partner is not a viable means of assistance.

As such, forced engagement with the criminal justice system can be at best disempowering, and at worst, dangerous for a survivor of domestic violence. Scholars have long argued that mandatory interventions perpetuate the cycle of violence intrinsic to domestic abuse relationships by supplanting the abuser's power and control with the authority of the state.$^{99}$ For example, Professor Aya Gruber explains that when a victim is not permitted to drop charges against her partner, her voice is not only ignored, but her choice may be held against her. "In an effort to make her change her mind," Gruber writes, "the state uses its own coercive powers to counter the assumed duress she has been placed under by her partner." ${ }^{\prime 100}$ The empowerment that domestic violence lawyers and advocates

97. Nichole M. Mordini, Note, Mandatory State Interventions for Domestic Abuse Cases: An Examination of the Effects on Victim Safety and Autonomy, 52 DRAKE L. REV. 295, 323 (2004).

98. Interview with [name and title withheld to protect privacy], Genesis Women's Shelter, in Dallas, Tex. (2016).

99. See, e.g., Epstein, supra note 83, at 135-36 (“. . by embracing the state as an ally, victims find themselves seeking redress from a criminal justice system that can perpetuate the kinds of power and control dynamics that exist in the battering relationship itself. In many cases, prosecutors take complete control over the case, functioning as the sole decision-maker and ignoring the victim's voice, wishes, and ideas.").

100. Aya Gruber, Neofeminism, 50 Hous. L. REV. 1325, 1366 (2013) (citing Laurie S. Kohn, The Justice System and Domestic Violence: Engaging the Case but Divorcing the Victim, 32 N.Y.U. REV. L. \& SOC. CHANGE 191, 203 ("Prosecutors may subpoena [domestic violence] victims and sometimes may incarcerate them to compel their testimony.")). Professor Gruber goes on to note the hypocrisy of the state in such cases, for while the state "divests abuse survivors of agency" in disregarding their choice not to prosecute, "prosecutors have no problem treating those same survivors as agents when they have the misfortune of becoming defendants," for example, in cases where they are accused of failing to intervene to protect their children from abuse or neglect. "In such cases, the state routinely maintains that battered women are free agents, capable of leaving their abusive situations and seeking redress through nonviolent and official means." Id. at 1368 . In one outrageous example, a Florida judge berated and then imprisoned a sobbing domestic violence survivor for failing to appear in court, even after the single mother informed the court that she was homeless and battling depression and anxiety as a result of the abuse she suffered. Kate Briquelet, Judge Berates Domestic Violence Victim-Then Sends Her to Jail, DAILY BEAST, Oct. 9, 2015, 1:00 AM ET, $\mathrm{http}: / / \mathrm{www}$. thedailybeast.com/articles/2015/10/09/judge-berates-domestic-violence-victim-andthen-sends-her-to-jail.html [https://perma.cc/SA2H-N5AU]. 
strive to attain for their clients is thwarted by a system that discounts their desires and dictates the manner in which they address the abuse they face.

Moreover, once victims are forced to work within a system against their will, with official actors they believe are not acting in their best interest and who achieve results that are not necessarily beneficial to their lives or safety, they may be reluctant to seek any form of help in the future, which could increase the level of risk and danger they face in their relationships. Mandatory arrest and prosecution could also have the unintended "effect of realigning the battered woman with the batterer." 101 A survivor of domestic violence may come to see her abuser as the victim of a system that perpetrates harm against him and possibly their family, which can lead her to seek to "protect him, and to [thereby] further entrench her in the abusive relationship." 102 In the most extreme cases, a woman who is subpoenaed and forced to testify against her abuser may be "willing to perjure herself rather than testify against her partner. In some jurisdictions, this choice will result in the victim being prosecuted for making a decision that she felt was in her best interest." 103

The stripping of agency from survivors though either mandatory or coercive interaction with law enforcement troubles domestic violence advocates, in part because their primary goal is to empower victims who have been subjected to abusive power and control. Forced engagement with law enforcement does not allow a survivor of domestic violence to control the means in which she extricates herself from a potentially violent relationship. It also does not permit victims to determine their own goals and priorities or to assess their own risks. For example, it does not allow them to weigh whether they would rather continue to receive critical financial, transportation, or childcare assistance from the abuser, which would disappear if the abuser was incarcerated and potentially deported. ${ }^{104}$ Autonomy and agency are deprived from victims when separation is the only recognized goal. As Professor Leigh Goodmark explains: “. . . almost all of these [mandatory] legal interventions are premised on the notion that battered women want to end their relationships, invoke the power of the legal system to keep their batterers away, and ultimately sever all ties with their abusers." 105 This paternalistic approach is also ineffective. An attempt to use law enforcement intervention to hasten a victim's departure from a relationship is likely doomed to fail, particularly considering the statistic that a victim leaves a

101. Linda G. Mills, Killing Her Softly: Intimate Abuse and the Violence of State Intervention, 113 HARV. L. REV. 550, 595 (1999).

102. Mordini, supra note 97 , at 320.

103. Id.

104. As discussed infra Section III.C, the economic consequences of separation, particularly for a woman who has survived domestic abuse, can be severe, often plunging a survivor into poverty or even homelessness.

105. Goodmark, Law Is the Answer?, supra note 68, at 8. 
violent relationship on average seven times before she is able to permanently extricate herself from the situation. ${ }^{106}$

Ultimately, although the move towards mandatory interventions is understandable when viewed in a historical context, and some benefits may arise from facilitating survivors' access to state protection, the harms to victims outweigh the advantages. Professor Linda Mills sums up the shortcomings bluntly and starkly: " $[\mathrm{m}]$ andatory state interventions, even when sponsored by feminists ... are in danger of replicating the rejection, degradation, terrorization, social isolation, missocialization, exploitation, emotional unresponsiveness, and close confinement that are endemic to the abusive relationship."107

While forced engagement with law enforcement is problematic for any survivor of domestic violence, as discussed in the following Section, the negative impacts are compounded for immigrant women. Critiques of mandatory interventions therefore illuminate the troubling nature of the $U$ visa's law enforcement certification requirement and raise significant questions about the wisdom of expansion of mandatory interventions into the immigration realm.

\section{BARRIERS TO COOPERATION FACED BY IMMIGRANT SURVIVORS OF DOMESTIC VIOLENCE}

While survivors of domestic violence may be reluctant to involve law enforcement, or the state generally, in their lives for the reasons discussed above, immigrant women face unique challenges and obstacles when engaging with law enforcement. Cultural, economic, political, linguistic, social, and legal considerations may make immigrant survivors unwilling, or sometimes even unable, to report abuse to law enforcement (or continue to cooperate after a report has been made). As receipt of the $U$ visa is conditioned upon such cooperation with law enforcement, the precise population the visa seeks to protect is often left without recourse. This Section will elaborate on these barriers to cooperation and ensuing hardships to survivors and their families, including language access, fear and distrust of law enforcement, familial and economic considerations, and separation violence.

\section{A. Language Barriers}

Many immigrant women may not know how to report crimes in the United States. Language poses a significant barrier to accessing help. It is perhaps not surprising that many immigrants speak a language other than English at home,

106. 50 Obstacles to Leaving: 1-10, NAT'L DOMESTIC VIOLENCE HOTLINE, June 10, 2013, http://www .thehotline.org/2013/06/50-obstacles-to-leaving-1-10/ [https://perma.cc/R6L4-C77Q].

107. Mills, supra note 101, at 551. 
but the 2010 census revealed the prevalence of foreign languages in the United States. For example, at least 145 languages are spoken in the Houston metro area, with 37 percent of the population speaking a language other than English at home. ${ }^{108}$ The New York metro area has the highest number of languages spoken at 192, while the Los Angeles metro area boasts the highest percentage- $54 \%$ of non-English speakers. ${ }^{109}$

If a victim does not speak English, she may be unaware of the resources available to her or unable to access the resources of which she is aware. Experts have identified language barriers as "pos[ing] the greatest hardship" to immigrant victims' reporting of crimes. ${ }^{110}$ I recall a client, Anjali, ${ }^{111}$ whom I represented when I was an attorney at a nonprofit organization that provided legal assistance to immigrant survivors of gender-based violence. She was brought to the United States from India under false pretenses of marriage and found herself trapped in a man's home, forced into domestic servitude, and made to endure both physical and sexual abuse. Thankfully, Anjali eventually escaped with the aid of a vigilant neighbor.

When I asked my client about her time in captivity, she informed me with dismay that she did not understand why help had not come sooner, for any time she was able to access a telephone without her captor noticing, she had diligently dialed 119. Stories like Anjali's illustrate how significant the language barrier can be for immigrant survivors of domestic violence. Even the most basic information and services-such as the 3-digit number to call in the event of an emergency-can be inaccessible to immigrant victims.

Even if they are aware of such services, immigrant survivors are often not able to utilize them to the same extent as English-speaking survivors, as they "may not have access to bilingual shelters ... it is also unlikely that they will have the assistance of a certified interpreter in court, when reporting complaints to the police or a 911 operator, or even acquiring information about their rights and the legal system." 112 With U visa eligibility contingent on reporting domestic violence to law enforcement, the inability of some immigrant victims to access

108. See Press Release, U.S. Census Bureau, No. CB15-185, Census Bureau Reports at Least 350 Languages Spoken in U.S. Homes (Nov. 3, 2015), http://www.census.gov/newsroom/press-releases 12015/cb15-185.html [https://perma.cc/68YF-SD2Y].

109. Id.

110. Davis \& Erez, supra note 42. See also U.S. COMM'N ON CrvIL RIGHTS, supra note 53, at 15; Carolyn Murdaugh et al., Domestic Violence in Hispanics in the Southeastern United States: $A$ Survey and Needs Analysis, 19 J. FAM. VIOLENCE 107, 111 (2004) ("The most frequently reported important barrier that kept women from getting needed services was language, either not being able to speak English or not having a translator.").

111. "Anjali" is a pseudonym, used here to protect the client's privacy.

112. Futures Without ViolenCe, The Facts on IMMigrant WOMEN AND DOMESTiC Violence (2016), available at http://www.futureswithoutviolence.org/userfiles/file/Children_and_Families /Immigrant.pdf [https://perma.cc/37TS-KMEC]. 
such resources leaves the most isolated and at-risk individuals without police or immigration protections.

\section{B. Fear or Distrust of Law Enforcement}

Many immigrants have complex feelings about and complicated relationships with law enforcement. Their experiences, both in their home countries and in the U.S., impact their view of domestic violence and the resources available to escape it.

\section{Experiences in Country of Origin}

An immigrant's experience and understanding of domestic violence is "shaped by an ongoing interplay between [her] current sociocultural context and that of the country of origin." countries where domestic violence is not considered a crime, or is even condoned. ${ }^{114}$ If a victim's home country did not have criminal or social service systems in place to respond to intimate partner violence, if calls for help were routinely ignored by law enforcement, or if a victim did not have access to a safe space (such as a shelter) to escape abuse, she would have no context for seeking such services in the United States. Studies have found that because of their experiences in their home countries, "[m]any immigrants ... are not aware or accepting of [intimate partner violence (IPV)] as a criminal offense."115

Moreover, even if an immigrant survivor were aware of the potential assistance law enforcement could provide, she might still be reluctant to reach out for help due to negative associations with official state actors in her home country. For example, "[p]eople from Latin America share a common regional heritage marked by abuse inflicted at the hands of governmental officials, the military, and local law enforcement officers." 116 With this background, it should perhaps be unsurprising that the police are not seen as positive forces in many

113. Mieko Yoshihama, Immigrants-in-Context Framework: Understanding the Interactive Influence of Socio-Cultural Contexts, 24 Evaluation AND PROGRAM PLAN. 307, 315 (2001).

114. In fact, only recently, in the name of bolstering "traditional family values," a law decriminalizing certain forms of intimate partner violence was enacted in Russia. Women in the World Staff, Putin Signs Amendment Decriminalizing Domestic Violence in Russia, N.Y. TIMES, Feb. 8, 2017, $\mathrm{http}: / /$ nytlive.nytimes.com/womenintheworld/2017/02/08/putin-signs-amendment-decriminalizingdomestic-violence-in-russia/ [https://perma.cc/3DX7-G6LH]

115. Raj \& Silverman, supra note 44, at 370 . Experts have noted that "immigrants frame their current experiences using their home countries as a point of reference," so if resources for domestic violence survivors did not exist in their country of origin, they would understandably infer "that the same applies in the destination countries." Menjivar \& Salcido, supra note 47, at 910.

116. Jenny Rivera, Domestic Violence Against Latinas by Latino Males: An Analysis of Race, National Origin, and Gender Differentials, 14 B.C. THIRD WORLD L.J. 231, 245 n.78 (1994). 
immigrants' lives. As the International Association of Chiefs of Police explains, immigrants from developing countries have an image of law enforcement that is "drastically different than that within the United States. Often the police in some of these countries are perceived as violent, corrupt and ineffective. These perceptions are often transferred to the immigrants' perception of the American police as well, creating a general reluctance to seek law enforcement assistance." 117 Such perceptions "also influence crime underreporting within immigrant communities, particularly domestic violence, sexual assault and gang activities."118

\section{Inequality and Bias in Policing}

Although experiences with law enforcement in immigrants' home countries can sometimes explain their reluctance to engage with officials in the United States, our domestic police force is not without culpability. As discussed above in Section II.C.3, a significant critique of mandatory interventions in cases of domestic violence is the effect and impact of such policies on minority communities. Many immigrant, African American, and Latino communities simply do not trust the police. ${ }^{119}$ Victims of color may therefore be hesitant or even afraid to report crimes to law enforcement because of "legitimate concerns that they will be subjected to differential treatment because of their ethnicity, gender, and immigration status." ${ }^{220}$ Such concerns are intensified when the racial or ethnic composition of a police force does not match that of the neighborhood it is policing. ${ }^{121}$ Moreover, as previously discussed, "victims whose batterers are African American may be particularly hesitant to send their batterer to jail if they view the system as oppressive or racist." 122

117. IACP, supra note 51 at 21.

118. Id.

119. See Tom R. Tyler, Policing in Black and White: Ethnic Group Differences in Trust and Confidence in the Police, 8 POLICE Q. 322, passim (2005).

120. Edna Erez \& Carolyn C. Hartley, Battered Immigrant Women and the Legal System: A Therapeutic Jurisprudence Perspective, 4 W. CRIM. REV. 155, 158 (2003). See also What to Do Instead of Calling the Police: A Guide, A Syllabus, A Conversation, A Process, TRUE BLUE POL., July 9, 2016, $\mathrm{http} / /$ www.truebluepolitics.com/2016/07/09/what-to-do-instead-of-calling-the-police-a-guide-asyllabus-a-conversation-a-process/ [https://perma.cc/3PMA-NJ72].

121. See Jeremy Ashkenas \& Haeyoun Park, The Race Gap in America's Police Departments, N.Y. TIMES, Apr. 8, 2015, https://www.nytimes.com/interactive/2014/09/03/us/the-race-gap-in-americas -police-departments.html [https://perma.cc/F79Y-5KYH].

122. Lauren Bennett et al., Systemic Obstacles to the Criminal Prosecution of a Battering Partner: $A$ Victim Perspective, 14 J. INTERPERSONAL VIOLENCE 761, 769 (1991). 
Such concerns may be particularly heightened now, when public confidence in law enforcement is at a 22 -year low. ${ }^{123}$ After a series of well-documented shootings of unarmed Black men ${ }^{124}$ by police, and the ensuing protests and activism by groups such as Black Lives Matter, the belief that law enforcement will exercise sound discretion in interactions with minority communities has been called into question. For example, in Chicago, the Mayor's Police Accountability Task Force found that city's police department to have a "history of racial disparity and discrimination in police practices." ${ }^{125}$ The perception of racial bias can have a real-life impact on reporting. A 2016 study found that a publicized incident of police violence against an unarmed Black man led to a decrease in reporting of crime that lasted over a year and resulted in a total net loss of approximately 22,200 calls for service. ${ }^{126}$

Issues of racial bias, discrimination and mistreatment are prevalent, and frequently highlighted, in the African American community, but similar concerns exist in immigrant communities as well. For example, "Latinas are suspicious of police who have acted in a violent and repressive manner toward the community at large." 127 When facing violence in her home and deciding whether or not to seek police assistance, a Latina's calculus is complex, as she "must decide whether to invoke assistance from an outsider who may not look like her, sound like her, speak her language, or share any of her cultural values." 228 A shocking example of hostility towards immigrants by law enforcement is the story of a woman of Asian descent who called the police when her husband violated the restraining order she had obtained against him. When the officer arrived, he refused to assist her, telling her that she should instead "go

123. Jeffrey M. Jones, In U.S., Confidence in Police Lowest in 22 Years, GALLUP NEwS, June 19, 2015, http://www.gallup.com/poll/183704/confidence-police-lowest-years.aspx [https://perma.cc/3FWW -LC6J].

124. Although the killings of Black men and boys like Trayvon Martin, Eric Garner, Michael Brown, Alton Sterling, and Philando Castile have received significant attention, Professor Kimberlé Crenshaw argues that Black women are also "routinely killed, raped, and beaten by the police, [but] their experiences are rarely foregrounded in popular understandings of police brutality...." AFriCAN AMERICAN POLICY Forum, \#SAYHERNAME: RESISTING POLICE BRUTALITY AGAINST BLACK WOMEN 1 (2015), available at $\mathrm{https}: / /$ static 1 .squarespace.com/static/53f20d90e4b0b80451 $158 \mathrm{~d} 8 \mathrm{c} / \mathrm{t} / 555 \mathrm{e} 2412 \mathrm{e} 4 \mathrm{~b} 0 \mathrm{bd} 5 \mathrm{f} 4 \mathrm{da} 5 \mathrm{~d} 3 \mathrm{a} 4 / 1432232978932 /$ SAYHERNAME+Social+Media+Guide .compressed.pdf [https://perma.cc/AQ8Z-Y86A]. Thus, when discussing issues of police violence in minority communities, it is important to remember that while male victims have become the face of the problem, women are also significantly impacted.

125. Police ACCOUNTABILITy TASK FORCE, RECOMMENDATIONS FOR REFORM: Restoring Trust Between the Chicago Police and the Communities They Serve 41 (2016), available at https://chicagopatf.org/wp-content/uploads/2016/04/PATF_Final_Report_4_13_16-1.pdf [https://perma.cc/D9WT-WED4].

126. Matthew Desmond et al., Police Violence and Citizen Crime Reporting in the Black Community, 81 AM. SOC. REV. 857 (2016).

127. Rivera, supra note 116 , at 246.

128. Id. 
back to where she belongs." ${ }^{\prime 29}$ Facing the possibility that a call to police will not result in help, many immigrant survivors of domestic violence understandably never pick up the phone.

\section{Fear of Deportation}

\section{i. Local Police as Immigration Enforcement}

Immigrants' fear of deportation is a significant factor in their unwillingness to engage with law enforcement. ${ }^{130}$ For many undocumented individuals, local police are indistinguishable from immigration enforcement, and concerns that they will be asked about their immigration status when reporting a crime can cause noncitizens to remain in dangerous situations. According to one study, fear of immigration consequences kept 21.7 percent of battered immigrants from leaving their abusers. ${ }^{131}$ Fear of being reported to immigration authorities and of deportation have been identified "as either the first or second most intimidating factors that kept battered immigrants from seeking the services they needed to end the abusive relationship...."132

Such concerns are particularly acute now, as the Trump administration has signaled its intent to increase reliance on programs such as $287(\mathrm{~g})^{133}$ and Secure Communities, which deputize local law enforcement as federal immigration

129. Linda Kelly, Stories from the Front: Seeking Refuge for Battered Immigrants in the Violence Against Women Act, 92 Nw. U. L. REV. 665, 679 (1998).

130. See, e.g., Hoan N. Bui, Help-Seeking Behavior Among Abused Immigrant Women: A Case of Vietnamese Women, 9 VIOLENCE AGAINST WOMEN 207 (2003); Reina et al., supra note 91, at 593, 600-01; Elizabeth Zadnik et al., Violence Against Latinas: The Effects of Undocumented Status on Rates of Victimization and Help Seeking, 31 J. INTERPERSONAL VIOLENCE 1141 (2016); Battered Immigrant Women Protection Act of 1999: Hearing on H.R. 3083 Before the Subcommittee on Immigration and Claims of the H. Comm. on the Judiciary, 106th Cong. 55 (2000) (statement of Rep. John Conyers) ("Battered immigrant women and children were not able to appeal to law enforcement agencies and courts for protection because they simply feared being reported to the INS and deported.").

131. Mary Ann Dutton et al., Characteristics of Help-Seeking Behaviors, Resources and Service Needs of Battered Immigrant Latinas: Legal and Policy Implications, 7 GEO. J. OF POVERTY L. \& POL'Y, $245,293(2000)$.

132. Id.

133. 8 U.S.C. $\$ 1357(\mathrm{~g})$. Under the INA $\S 287(\mathrm{~g})$ program, Immigration and Customs Enforcement (ICE) enters into a Memorandum of Agreement with a state or local agency that permits ICE to delegate power over immigration enforcement to that agency. The delegated power allows the state or local agency to ascertain immigration status and arrest and detain undocumented immigrants. The agency then reports undocumented immigrants to ICE so ICE can assume custody and initiate deportation proceedings. See Memorandum of Agreement, U.S. Immigration and Customs Enforcement, https:// www.ice.gov/doclib/detention-reform/pdf/287g_moa.pdf [https://perma.cc/HFZ6-EH4C]; see also Delegation of Immigration Authority Section 287(g) Immigration and Nationality Act, U.S Immigration and Customs Enforcement (Oct. 3, 2014), https:/www.ice.gov/factsheets $/ 287 \mathrm{~g}$ [https:// perma.cc/27RY-MVN5]. 
agents. ${ }^{134}$ A January 25, 2017, Executive Order included language that blocked federal funding for so-called "Sanctuary Cities" that refuse to cooperate with the federal government's immigration enforcement efforts. ${ }^{135}$ States such as Texas were quick to follow suit with their own Sanctuary City bans. ${ }^{136}$ The impact on vulnerable immigrant communities was significant and swift; a 2017 survey of over 700 advocates working with victims of intimate partner violence, sexual abuse, and human trafficking revealed that 43 percent of advocates had clients who dropped a civil or criminal case due to fear of immigration enforcement. ${ }^{137}$

\section{ii. Abuse of Discretion in U Visa Certification}

Although the U visa was created to address immigrants' fear of deportation, the risk associated with reaching out to police may exceed the potential benefit. Deportation means separation from one's home, family and children, potentially indefinitely, as well as a loss of income and the possibility of increased violence in one's home country. ${ }^{138}$ Alerting law enforcement to a crime, on the other hand, does not necessarily guarantee access to $U$ nonimmigrant status, because police and prosecutors retain discretion to sign (or, often, not sign) the certification form that is necessary to obtain status. Officers in a particularly hostile or antiimmigrant jurisdiction may detain and turn victims over to Immigration and Customs Enforcement (ICE) without notifying them of potential eligibility for $U$ nonimmigrant status or providing them with the opportunity to apply for such status. Law enforcement agencies are not mandated to sign $U$ visa certification forms, and many jurisdictions have either opted out or passed onerous limitations

134. Enhancing Public Safety in the Interior of the United States, Exec. Order No. 13,768, 82 Fed. Reg. 8799 (Jan. 25, 2017), available at https://www.whitehouse.gov/the-press-office/2017/01/25 /presidential-executive-order-enhancing-public-safety-interior-united [https://perma.cc/TV2U3L7A]. Section 8(a) of the Executive Order, entitled "Federal-State Agreements," states: "[i]n furtherance of this policy, the Secretary shall immediately take appropriate action to engage with the Governors of the States, as well as local officials, for the purpose of preparing to enter into agreements under section $287(\mathrm{~g})$ of the INA (8 U.S.C. $\$ 1357(\mathrm{~g})$ )." Section 8(b) states: "[ $\mathrm{t}] \mathrm{o}$ the extent permitted by law and with the consent of State or local officials, as appropriate, the Secretary shall take appropriate action ... to authorize State and local law enforcement officials ... to perform the functions of immigration officers in relation to the investigation, apprehension, or detention of aliens in the United States. .. . Such authorization shall be in addition to, rather than in place of, Federal performance of these duties."

135. Id.

136. Niraj Chokshi, Texas Governor Signs a Ban on Sanctuary Cities, N.Y. TIMES, May 7, 2017, https://www.nytimes.com/2017/05/07/us/texas-governor-signs-ban-sanctuary-cities.html [https:// perma.cc/RZ5E-XWKQ].

137. TAHIRIH JustiCE CTR., KEy FIndINGS: 2017 ADVOCATE AND LEGAL SERVICE SURVEY REgARDING IMMIGRANT SURVIVORS (2017), available at $\mathrm{http}: / / \mathrm{www}$.tahirih.org/wp-content/uploads/2017/05 /2017-Advocate-and-Legal-Service-Survey-Key-Findings.pdf [https://perma.cc/E4MM-GANB].

138. This violence can stem from many sources, including at the hands of an abuser, the abuser's family, or the government in a politically unstable nation. 
on certification. ${ }^{139}$ An agency may withhold a signature even if a victim reports and is fully cooperative with any ensuing investigation or prosecution, making her vulnerable to deportation by self-identifying to law enforcement. And if a victim ceases to cooperate at any time-even if she does so due to threats of retaliatory harm by the batterer-the agency can even withdraw a previously signed certification. ${ }^{140}$

In reviewing just one day of activity on a national listserv for attorneys and advocates dedicated to representing immigrant survivors, issues with law enforcement's exercise of discretion with respect to $U$ visa certification were ubiquitous. A litany of problems were identified, including a challenge in obtaining a $U$ visa certification for a victim of statutory rape; concern about USCIS' notice of intent to revoke a U visa granted 7 years earlier due to "an improperly executed I-918B"; and questions about the feasibility of obtaining a $U$ visa for a victim of domestic violence who had been erroneously identified as a perpetrator by first responders. ${ }^{141}$ In the last instance, an officer concluded that a pregnant woman was the offender because her husband had scratches on his neck, despite the fact that she reported acting in self-defense after he sat on her abdomen and strangled her, causing her to go into labor. ${ }^{142}$ In each of these cases, a misuse or abuse of police discretion made already vulnerable victims more vulnerable, including through risk of deportation by identifying survivors to law enforcement or immigration authorities.

The experiences detailed in these anecdotes have been confirmed as pervasive by a number of empirical studies that reveal a shocking lack of consistency among $U$ visa certification processes nationwide. The discretion that rests with law enforcement agencies has resulted in what advocates have termed "geographic roulette," wherein victims in identical circumstances are either

139. For example, the Dallas, Texas, Police Department required, among other things, that victims submit certification requests within one year of the crime, and document physical harm suffered as a result of their victimization. These ultra vires requirements pose significant roadblocks to access for survivors. And even when jurisdictions do not have official policies that limit or restrict $U$ visa access, police may simply refuse to sign certification forms. In responding to a question posed on a listserv for humanitarian immigration attorneys regarding the New York Police Department's (NYPD) denial of a certification request, one senior lawyer quipped, "as I think many others have already said, NYPD won't grant certs ... if they don't feel like it." Email from VAWAExperts listserv, Daily Digest Number 6230 (Mar. 24, 2016) (on file with author).

140. A recent decision from the Administrative Appeals Office of the U.S. Citizenship and Immigration Services upheld the agency's denial of a U visa petition for a survivor of domestic violence who refused to press charges against her abuser "because she feared retaliation and because he threatened to have her deported and take away her daughters." In re: Petitioner: [redacted], 2013 WL 5296790 (I.N.S. Mar. 27, 2013).

141. Email from VAWAExperts listserv, Daily Digest Number 6377 (July 13, 2016) (on file with author). 142. Id. 
granted or denied certification depending on the location of the agency from which they seek it. ${ }^{143}$

A study by the University of North Carolina School of Law Immigration/Human Rights Policy Clinic revealed that 165 law enforcement agencies, located in 35 states, refused to execute certification forms for victims under any circumstances. ${ }^{144}$ Eighty percent of advocates responding to that survey reported engaging with an agency that had a limited certification policy. ${ }^{145}$ The National Immigrant Women's Advocacy Project conducted a similar survey of 772 victim and legal service providers in 49 states. Participants in that study reported a litany of explanations provided by law enforcement agencies for refusing to sign certifications. Nearly all of the stated reasons were ultra vires or contrary to the $\mathrm{U}$ visa statute or regulations. They included denials because the crime happened too long ago; because no prosecution, arrest or conviction had occurred; because the law enforcement agency determined that the victim did not suffer substantial harm; or simply because the agency did not want to grant legal status. ${ }^{146}$

These studies demonstrate that law enforcement agencies across the United States have both formal and informal policies that are not in keeping with Congress' intent to provide immigration relief to victims who have assisted at various stages of investigations and prosecutions (including those who have been helpful, are currently being helpful, or are likely to be helpful in investigating or prosecuting the criminal activity). ${ }^{147}$ In the current climate, legitimate victims are capriciously denied the opportunity to seek U visas. For example, in Spring Lake, Minnesota, the Chief of Police stated that he "would not feel 'comfortable' certifying U visa applications to anyone that he did not know personally."148 Such abuses of discretion serve to make geography, as opposed to merit, the most significant deciding factor in whether or not a survivor receives potentially life-

143. JeAn ABreu et AL., Univ. N.C. SCh. OF LAW IMMigration/Human Rights Policy Clinic, The POLITICAL GEOGRAPHY OF THE U VISA: ELIGIBILITY AS A MATTER OF LOCALE 22 (2014), available at http://www.law.unc.edu/documents/clinicalprograms/uvisa/fullreport.pdf [hereinafter "UNC Report'].

144. Id. at 27 . A blanket refusal to certify is contrary to not only Congressional intent but the $\mathrm{U}$ visa regulations themselves, which encourage "certifying agencies to develop internal policies and procedures" to ensure certification of victims. U Visa Regulations, supra note 18.

145. ABREU ET AL., supra note 143 at 28 . The authors of the report argue that policies that either prohibit or significantly restrict certification may cause preemption issues if they conflict with and result in circumvention of federal law. Id. at 77-80.

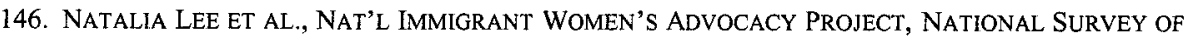
SERVICE PROVIDERS ON POLICE RESPONSE TO IMMIGRANT CRIME VICTIMS, U VISA CERTIFICATION AND LANGUAGE ACCESS 13 (2013), available at http://www.niwap.org/reports/Police-Response-UVisas-Language-Access-Report-4.6.13.pdf [https://perma.cc/J9TG-ED7Y].

147. 8 U.S.C. $\$ 1101(\mathrm{a})(15)(\mathrm{U})(\mathrm{i})(\mathrm{III})(2012)$.

148. UNC Report, supra note 143 , at 20. 
saving immigration status-a far cry from what the $U$ visa was intended to achieve.

Ultimately, overreliance on police officers' proper use of discretion in the $U$ visa context has meant that an immigration remedy that was intended to eliminate fear of reporting to law enforcement often does not aid the very victims it was created to assist.

\section{iii. Deportation as a Tool of Abuse}

Fear of deportation is felt in most immigrant communities, but victims of domestic violence, whom the $U$ visa is primarily intended to protect, may be especially afraid due to distortions or lies about the immigration process and justice system implanted by their abusers. Batterers "often use their partner's immigration status, fear of law enforcement and misinformation about the U.S. legal system as tools to exert power and coerce the partner into staying in the situation." 149 The "Immigrant Power and Control Wheel," a document widely used by domestic violence advocates, details various immigration-related forms of abuse from the most direct, such as "threatening ... to get her deported," to those with roots in economic abuse, such as "threatening to report her if she "works under the table," or forms of control, such as "withdrawing or threatening to withdraw papers filed for her residency." 150

If an abusive partner has lawful immigration status but the victim does not, the status imbalance leads to a power imbalance. As an official with the legacyImmigration and Naturalization Service (INS) explained, immigration enforcement processes can be a powerful weapon in abusers' hands. Tactics include "threatening to report a family member to the INS, making false promises to file a petition sometime in the future, withdrawing a petition that has already been filed, withholding important documentation, or refusing to appear for the scheduled interview with INS."151

149. IACP, supra note 51 , at 29.

150. NAT'L CTR. ON DOMESTIC VIOLENCE, IMMIGRANT POWER AND CONTROL WHEEL (2009), available at http://www.ncdsv.org/images/Immigrant $\% 20 \mathrm{P} \& \mathrm{C} \% 20$ wheel $\% 20$ NO $\% 20$ SHADING $\% 20-\% 20$ NCDSV-ICE_updated2009.pdf [https://perma.cc/SUT3-378V]. The Power and Control Wheel was created by the Domestic Abuse Intervention Project in Duluth, Minnesota. The wheel organizes and describes the most common abusive tactics used in domestic violence relationships and is regularly used by counselors to help survivors identify how batterers used each behavior identified on the wheel against to perpetrate abuse. Since the original wheel was developed in 1984, it has been adapted for specific communities of survivors (e.g., immigrants, people with disabilities, gays and lesbians, Muslims, etc.) in order to identify the unique vulnerabilities presented by those statuses.

151. Battered Immigrant Women Protection Act of 1999: Hearing on H.R. 3083 Before the Subcommittee on Immigration and Claims of the H. Comm, on the Judiciary, 106th Cong. 40 (2000) (statement of Barbara Strack, Acting Executive Associate Commissioner for Policy and Planning, Immigration and Naturalization Service). 
Of course, a true disparity in immigration status need not exist for it to be used as a tool of abuse. A client I represented in a petition for relief under the Violence Against Women Act, which requires that the victim of domestic violence be married to either a U.S. Citizen or Lawful Permanent resident, was utterly certain that her abuser was lawfully in the U.S. because he regularly mocked her after beatings, challenging her to call the police who he said would not arrest him but instead deport her for being "illegal." We submitted her application, and it was ultimately denied, because my client's husband was in fact undocumented himself. His abuse and deception knew no bounds - he had even shown her a fraudulent "Green Card"-and demonstrate the power that threats of deportation can wield in an abusive relationship.

\section{Dual Arrest}

Lastly, immigrant domestic violence survivors' fear of arrest and subsequent deportation is not necessarily misplaced, not only due to aggressive immigration enforcement policies, but because of the ubiquity of "dual arrests." Dual arrests have been found to be a direct result of mandatory arrest policies. If officers responding to a family violence call cannot easily, immediately, or readily determine the primary aggressor in a situation, they may arrest both parties, including the potential victim, with the thought that the court system will "work it out" at a later date.

Studies have demonstrated that mandatory intervention policies increase domestic violence arrest rates for women. ${ }^{152}$ For example, in Wisconsin, women made up 13 percent of all domestic violence arrests prior to the enactment of a mandatory arrest law; after the law was passed, the percentage of women arrested rose dramatically, almost doubling to 23.9 percent. ${ }^{153}$ Similarly, in Washington state, which was one of the first jurisdictions to institute a mandatory arrest policy, reports of the arrest of victims along with their abusers was "attributed to ... inadequate police training, officer fear of liability for failing to protect men who complained of assault, and officer resentment toward the limitation of their

152. See Shamita D. Dasgupta, A Framework for Understanding Women's Use of Nonlethal Violence in Intimate Heterosexual Relationships, 8 VIOLENCE AGAINST WOMEN 1364 (2002) (summarizing studies of increased rates of arrests of women, including those due to dual and mandatory arrest). Dasgupta notes that women taken into police custody as initiators of violence were in most cases battered themselves, but because they were not identified as victims, "the contexts of their violence ... remained invisible." Id. at 1375 . She calls for increased training that would allow officers to differentiate between defensive and non-defensive violence and to identify a predominant aggressor in situations of domestic abuse. Such training, she suggests, would mitigate problems surrounding mandatory arrest policies. Id. at 1382. See also Maguigan, supra note 69, at 442-43.

153. See JOAN ZORZA \& LAURIE WOODS, NAT'L CTR. ON WOMEN AND FAMILY LAW, MANDATORY ARREST: PROBLEMS AND POSSIBILITIES 17 (1994). 
discretion in domestic violence cases." ${ }^{154}$ Officers' mistaking self-defense for mutual combat can have disastrous long term consequences, ${ }^{155}$ particularly for an immigrant victim whose arrest may lead to deportation. ${ }^{156}$

For the many complex reasons described above, immigrant survivors of domestic abuse may be unable or unwilling to reach out to police, or to continue cooperating with police who become involved in their lives, when they experience family violence. Their fear and distrust of law enforcement, however rational, may leave them without critical legal and social protections. And although they are bona fide victims of domestic violence, in declining to engage with law enforcement, they are also ineligible under current law to benefit from immigration protections created with them in mind.

\section{Family Fracturing, Economic Consequences and Isolation}

Even if she believes that the police will help her, an immigrant woman may be unwilling to report domestic abuse because of the potential impact that engagement with law enforcement might have on her partner and family. Domestic violence and other gender-based crimes, such as stalking, protective order violations, or sexual violence, are deportable offenses. ${ }^{157}$ Thus, if an individual reports an abusive spouse with the goal of making the violence stop, or perhaps even having him receive a prison sentence as punishment for his actions, reporting could lead to significantly more serious unintended

154. Machaela M. Hoctor, Domestic Violence as a Crime Against the State: The Need for Mandatory Arrest in California, 85 CAL. L. REV. 643, 683 (1997). Scholars have also suggested that forcing police officers to arrest batterers did not necessarily change some officers' antiquated views about domestic violence. Officers therefore found ways to enforce mandatory arrest policies in such a way that the victim was penalized for seeking assistance. See Gruber, The Feminist War on Crime, supra note 69 , at 804 .

155. See Goodmark, supra note 68, at 23 ("Problems for the battered woman do not end with the arrest; she also faces the prospect of having her children removed by child protective services, being charged inappropriately, being pressured to plea bargain, being wrongfully convicted, having her arrest and conviction history used against her in subsequent custody proceedings, losing her job, and having the batterer use the threat of criminal prosecution to continue to control her."). It should also be noted that even if a woman is not arrested along with an abusive partner as part of a dual arrest, her involvement in the criminal justice system is likely related, as incarcerated women have typically "experience[ed] gender-based trauma throughout their lives. About eight in ten have experienced domestic partner abuse. A large majority have survived sexual violence." Michelle Chen, Why Are There So Many Women in Jail?, NATION, Aug. 22, 2016, https://www.thenation.com/article/whyare-there-so-many-women-in-jail/ [https://perma.cc/G9TY-ARP6].

156. A domestic violence conviction is a deportable offense. See 8 U.S.C. $\S 1227(a)(2)(E)(i)(2012)$ ("Any alien who at any time after admission is convicted of a crime of domestic violence, a crime of stalking, or a crime of child abuse, child neglect, or child abandonment is deportable.").

157. Id.; 8 U.S.C. $\$ 1227$ (a)(2)(E)(ii) (2012) ("Any alien who at any time after admission is enjoined under a protection order issued by a court and whom the court determines has engaged in conduct that violates the portion of a protection order that involves protection against credible threats of violence, repeated harassment, or bodily injury to the person or persons for whom the protection order was issued is deportable."). 
consequences for an undocumented perpetrator. A simple call to police might unwittingly initiate a process that leads to deportation, the potentially permanent loss of a woman's partner and her children's father, and the ensuing fracturing of a family and victim's economic stability.

Scholars have described immigrant women as experiencing a "double bind" wherein they are forced to achieve "empowerment through the disempowerment of a male member of the community."158 In a study of Chinese, Filipina and Latina undocumented survivors, researchers found that only 6 out of 413 women surveyed had called the police for help; the primary reason given for their silence was that "they [did] not want to cause their husband or partner's deportation."159 The study's authors described the double bind as not just adversely impacting a survivor's perceptions of her role in the community but also effecting her on an individual and personal level, "cutting her off from vital economic support, confronting her sense of cultural solidarity and undermining traditional value systems." 160

The damage done to a survivor as a result of her partner's deportation or long-term incarceration is more than philosophical or emotional. If the abuser is the primary breadwinner in a family-which is often the case where the batterer's exertion of power and control takes the form of economic abuse--his absence can be highly damaging for a woman and her children. Studies have shown that there is a 50 percent chance that a female victim of domestic violence will drop below the poverty line if she leaves her abuser. ${ }^{161}$ Domestic violence has also been revealed as a leading cause of homelessness for women. ${ }^{162}$

Thus, if a survivor sees her options as choosing between abuse and poverty, she may ultimately decide that the former provides greater safety and security for herself and her children. Studies have shown that many women make precisely this calculus. A study of immigrant Latinas who had experienced

158. Rivera, supra note 116, at 248. See also Michael Kagan, Immigrant Victims, Immigrant Accusers, 48 U. MICH. J.L. REFORM 915 (2015).

159. HOGELAND \& ROSEN, supra note 48, at 61; see also Edna Erez, Immigration, Culture Conflict and Domestic Violence/Woman Battering, 2 CRIME PREVENTION AND COMMUNITY SAFETY: AN INT'L J. 27, 31 (2000) ("Many immigrant battered women are also afraid that official action will lead to the deportation of their abusers, which in turn could mean loss of their own dependent immigrant status.").

160. Id.

161. See Lisa M. De Sanctis, Bridging the Gap Between the Rules of Evidence \& Justice for Victims of Domestic Violence, 8 YALE J.L. \& FEMINISM 359, 368 (1995) (citing NAT'L ClEARINGHOUSE FOR THE DEF. OF BATTERED WOMEN, STATISTICS PACKET (3d ed. Fed. 1994). A participant in a study of low-income survivors of domestic violence explained that she "avoided leaving her abusive husband for years because she feared losing the only wealth she had, her property and home." Cynthia K. Sanders, Economic Abuse in the Lives of Women Abused by an Intimate Partner: A Qualitative Study, 21 VIOLENCE AGAINST WOMEN 3, 15 (2014).

162. See ACLU WOMEN's RIGHTS PROJECT, DOMESTIC VIOLENCE AND HOMELESSNesS (2006), available at https://www.aclu.org/sites/default/files/pdfs/dvhomelessness032106.pdf [https://perma .cc/K95J-PJ3S]. 
physical and sexual abuse at the hands of their partners found that "the single greatest barrier to leaving an abusive relationship was lack of money."163

An immigrant woman may be particularly dependent on an abusive partner for financial support, childcare, housing, transportation, healthcare, or other critical needs. Foreign-born individuals are more likely to be lacking in formal education or employment skills and may be unable to work due to their immigration status. ${ }^{164}$ Moreover, without access to the welfare safety net that native-born survivors rely on, ${ }^{165}$ separation can threaten immigrant women's "tenuous hold on economic viability, for without the batterer's income or his assistance ... women may lose jobs, housing, and even their children."166

A woman experiencing domestic violence is likely to be insulated from the outside world, as such isolation is a frequently utilized tool of abuse. Immigrant survivors' separation may be intensified due to "lack of social contacts, geographic isolation, and limited mastery of English or cultural alienation," all of which allow the abusive partner to increase "marital dependence and ... intrafamilial exclusivity and intensity."167 An immigrant woman may also be uniquely dependent on her abusive partner and his family, as patrilocation is common in many immigrant cultures. ${ }^{168}$ With her social circle circumscribed, reporting to law enforcement and any subsequent adverse action taken against an abuser might leave an immigrant survivor without her only safety net.

Ultimately, because of the nature of both domestic abuse and the immigrant experience, "interventions that encourage battered women to take action based on a perspective of individual rights may be culturally incongruent and subsequently ineffective ...."169 An abused immigrant woman may value her

163. Dutton et al., supra note 131, at 295. See also Richard J. Gelles, Through a Sociological Lens: Social Structure and Family Violence, in CURRENT CONTROVERSIES ON FAM. VIOLENCE 31, 33-35 (1993) (reporting that wives with fewer resources were more likely to stay with violent husbands).

164. See RANDY CAPPS ET AL., URBAN INST., IMMIGRATION STUDIES PROGRAM, A PROFILE OF THE LOWWAGE IMMIGRANT WORKFORCE (2003), available at http://webarchive.urban.org/UploadedPDF /310880_lowwage_immig_wkfc.pdf [https://perma.cc/WRY9-ADMB].

165. See Leslye E. Orloff et al., With No Place to Turn: Improving Legal Advocacy for Battered Immigrant Women, 29 FAM. L.Q. 313, 324 (1995) ("[V]irtually all public assistance programs bar undocumented immigrants from receiving benefits and limit the eligibility of legal residents.").

166. Coker, supra note 57, at 1017-18.

167. Dutton et al., supra note 131 , at 252 . These issues are exacerbated if a married victim seeks a permanent separation from the abuser, as divorce carries great stigma in many immigrant communities. See Raj \& Silverman, supra note 44, at 384-85 ("For Asians, Latinos, and Middle Eastern immigrants, divorced victims are often blamed for breaking up their families and taking the father away from their children; both victims and children can be stigmatized and ostracized by their communities."). Because the end of a marriage may, for example, be seen as bringing shame upon a family, "community norms held by battered women's informal support systems consistently prevent abused women from leaving their partners or telling others of the abuse for fear of shaming their husbands and families." Id. at 384.

168. See Raj \& Silverman, supra note 44, at 371 (explaining that immigrant women "often live with or close to their husband's family due to cultural dictates and economic necessity").

169. Erez \& Hartley, supra note 120, at 160. 
family-both immediate and extended-as well as the economic and social stability that they provide, over her personal safety. This perspective challenges the basic tenets of the $U$ visa, which is focused on individual protection stemming from public action that may be incompatible with the greater needs of a family or community.

\section{Separation Violence}

Perhaps one of the most troubling aspects of conditioning receipt of the $U$ visa on cooperation with law enforcement is the flawed assumption that separation from an abusive partner resulting from arrest and prosecution will increase survivor safety. In fact, reporting domestic abuse to the police can put a victim of domestic violence in greater danger.

Because intimate partner violence is, at its core, about one person's desire to exercise power and control over another, a challenge to that dynamic will often cause the abuser to lash out and retaliate against a survivor who asserts herself by, for example, seeking external protection against violence. This phenomenon, known as "separation violence" or "separation assault," has been defined by Professor Martha Mahoney as:

the attack on the woman's body and volition in which her partner seeks to prevent her from leaving, retaliate for the separation, or force her to return. It aims at overbearing her will as to where and with whom she will live, and coercing her in order to enforce connection in a relationship. It is an attempt to gain, retain, or regain power in a relationship, or to punish the woman for ending the relationship. ${ }^{170}$

Engaging with law enforcement sends a clear signal that a victim will no longer tolerate abuse or the abuser's control and can therefore be a significant triggering event for separation assault. An arrest can also provide an abuser with an excuse to perpetuate further harm. He may blame the victim for his incarceration and seek retribution in the form of additional violence. He may seek to injure or kill her to prevent her from testifying. Retaliatory violence may even "be motivated by knowledge of supportive or protective resources for women, particularly in men who believe such services deprive them of their rightful authority or control in intimate relationships."171

170. Martha R. Mahoney, Legal Images of Battered Women: Redefining the Issue of Separation, $90 \mathrm{MICH}$. L. REV. 1, 65-66 (1991).

171. Laura Dugan et a1., Exposure Reduction or Retaliation? Effects of Domestic Violence Resources on Intimate-Partner Homicide, 37 LAW \& SOC'Y REV. 174 (2003). 
Regardless of the cause, the prevalence of separation violence is indisputable. The National Institute of Justice reported that attempting to leave a violent relationship was the precipitating factor in 45 percent of murders of a woman by a man. ${ }^{172}$ At least half of women who leave their abusers are followed and harassed or further attacked by them. ${ }^{173}$ A Canadian statistical analysis revealed that "half of the women who reported experiencing spousal assault by a past partner indicated that the violence occurred after the couple separated, and in one-third of post-separation assaults the violence became more severe or actually began after the separation. ${ }^{174}$ Ultimately, it is clear that ". . a little exposure reduction (or unmet promises of exposure reduction) in severely violent relationships [is] worse than the status quo."175

The stories behind the statistics are expectedly chilling. In Louisiana, a woman was gunned down by her abusive husband immediately outside of the courthouse after she had filed for both a protective order and divorce. ${ }^{176}$ The murder of a Dallas woman by her ex-husband was captured on a 911 call; as he strangled her to death, he demanded repeatedly, "did you call the police?"177 After a Las Vegas woman filed for divorce, her estranged husband regularly harassed and threatened her. ${ }^{178}$ She sought a protective order, which was denied, and a mere three weeks later, he shot and killed her, their three children, and himself. ${ }^{179}$

Cooperation with the authorities or engagement with other legal entities that present a threat to an abuser's power and control are a major cause of separation abuse. Violence has been documented at nearly every stage of the legal process. A study revealed that 20 percent of men arrested for domestic abuse re-assaulted

172. Carolyn R. Block, Intimate Partner Homicide, 250 NAT'L INST. OF JUST. J. 6 (2003), available at https://www.ncjrs.gov/pdffiles 1/jr000250.pdf [https://perma.cc/WG3J-RZZT].

173. Mahoney, supra note 170 , at 171 .

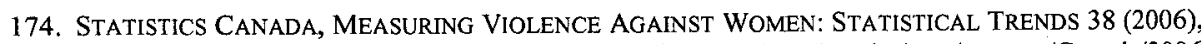
available at http://www.unece.org/fileadmin/DAM/stats/gender/vaw/surveys/Canada/2006 _Publication_VAW.pdf [https://perma.cc/A9FZ-B6N2].

175. Dugan et al., supra note 171 , at 194.

176. 146 Cong. Rec. 9,846 (Oct. 4,2000 ), available at https://www.congress.gov/crec/2000/10/04/CREC -2000-10-04-pt1-PgS9846.pdf.

177. Tanya Eiserer, 911 Tape Reveals Horrific Last Minutes for Murdered Dallas Woman, DALLAS MORNING NEWS, Mar. 2013, http://www.dallasnews.com/news/crime/headlines/20130306-dallas911-tape-reveals-horrific-last-minutes-for-woman-murdered-while-begging-for-help.ece [https:// perma.cc/GQ5H-TKW9].

178. Travis Gettys, Las Vegas Woman Denied Protection Order Three Weeks Before Husband Killed Her and Their Three Children, RAw STORY, July 6, 2016, http://www.rawstory.com/2016/07/las-vegaswoman-denied-protection-order-3-weeks-before-husband-killed-her-and-their-three-children/ [https://perma.cc/EH6F-5K93].

179. Id. 
their partner before the original criminal case was resolved in court. ${ }^{180}$ Allowing a victim to drop prosecution has been shown to result in the lowest rate of presettlement violence. ${ }^{181}$ Increased prosecution of protective order violations are associated with "increases in the homicide rate of white females, both married and unmarried ...." ${ }^{182}$ Lack of funding for witness protection programs further exacerbates these risks. And women in abusive relationships are keenly aware of this danger; in a comprehensive study, "fear of batterer" was listed as the number one reason that victims of domestic violence were unwilling to cooperate with the government. ${ }^{183}$

Ultimately, given overwhelming evidence that mandatory interventions may endanger the very lives they are purporting to save, one must question both adherence to such policies and their perpetuation of analogous ideas into new areas, such as $\mathrm{U}$ visa eligibility. For the numerous reasons detailed above, the criminal justice system is not capable of meeting the needs of many victims or securing their safety. Survivors therefore often make the rational decision to remain with their abusive partners, who are at least a known evil in their lives, instead of engaging with a system that may inflict additional and unknown harms. Sadly, this choice necessarily costs non-native victims security in their immigration status, an imbalanced tradeoff that could not have been the objective of those who created the $U$ visa to protect immigrant women.

\section{SOLUTIONS}

If the goal of policies such as mandatory arrest and no-drop prosecution is to remove discretion from law enforcement, there is a readily apparent concern in extending mandatory or coerced cooperation with law enforcement into the realm of immigration law. Requiring immigrant victims to cooperate in order to receive a $\mathrm{U}$ visa forces them to engage with the state, which in turn can put them at great risk, but does not demand reciprocal treatment or accountability from law enforcement.

Potential solutions to the problems raised by the $U$ visa certification process can be easily discerned by looking to other immigration remedies that are available to survivors of gender-based harms such as domestic violence and

180. David A. Ford, Preventing and Provoking Wife Battery Through Criminal Sanctioning: A Look at the Risks, in ABUSED AND BATTERED: SOCIAL AND LEGAL RESPONSES TO FAMILY VIOLENCE 191, 198 (Dean O. Knudsen \& JoAnn C. Miller, eds., 1991).

181. David A. Ford \& Mary J. Regoli, The Preventive Impacts of Policies for Prosecuting Wife Batterers, in Domestic VIolenCE: THE ChANGINg CRIMINAL Justice Response 181, 195 (Eve S. Buzawa \& Carl G. Buzawa eds., 1992).

182. Dugan et al., supra note 171 , at 194.

183. Edna Erez \& Joanne Belknap, In their Own Words: Battered Women's Assessment of the Criminal Processing System's Responses, 13 VIOLENCE \& VICTIMS 251, 260 (1998). 
human trafficking. For example, the immigration benefits conferred by the Violence Against Women Act require a survivor of domestic violence to demonstrate that she entered into a good faith marriage with either a U.S. citizen or Lawful Permanent Resident and that she was subjected to battery or extreme cruelty in that relationship. ${ }^{184}$ The grant of immigration status under VAWA is not conditioned on assistance to or cooperation with law enforcement; a survivor is entitled to relief based solely upon proof that she has suffered domestic violence.

The Violence Against Women Act's immigration provisions are precedent for a solely humanitarian conferral of benefits to survivors of domestic abuse: relief that is not dependent on a victim's engagement with law enforcement. As such, simply removing law enforcement certification from the $U$ visa eligibility requirements would not only be consistent with current immigration law, but would also allow the humanitarian aims of the $U$ visa to be achieved without any of the attendant costs entailed in engagement with police. Eliminating proof of cooperation with law enforcement would still leave in place the other criteria detailed in Section I.A, namely, proof that one is a victim of an enumerated crime, as well as evidence of substantial harm as a result of that victimization. As such, measures would remain in place to ensure that only "true" victims of domestic violence were afforded relief. Granting U nonimmigrant status without requiring engagement with law enforcement would go a long way not only in resolving many of the practical issues raised in Sections II and III above, but also in addressing the concerns raised by feminist scholars regarding the harms of mandatory or coercive interventions. ${ }^{185}$

Alternatively, the $\mathrm{T}$ visa, a form of immigration relief for survivors of human trafficking that was contemporaneously enacted with the $U$ visa in the Victims of Trafficking and Violence Prevention Act of 2000, is an example of an immigration remedy that achieves an appropriate balance between humanitarian and law enforcement aims. ${ }^{186}$ Like the $\mathrm{U}$ visa, an applicant for a $\mathrm{T}$ visa must demonstrate to USCIS that she has "complied with any reasonable requests for assistance in the Federal, State, or local investigation or prosecution of acts of trafficking." ${ }^{187}$ However, unlike U nonimmigrant status, T nonimmigrant status contains an opt-out provision for minors as well as those who are unable to cooperate due to physical or psychological trauma. ${ }^{188}$ Moreover, law

184. Survivors of domestic violence can obtain immigration relief under two distinct but related provisions of the Violence Against Women Act-the Self Petition process, 8 U.S.C.A. § 1154(a), and the Battered Spouse Waiver, 8 U.S.C. $\S 1186 \mathrm{a}(\mathrm{c})(4)(\mathrm{C})$.

185. See infra Section II.C.3.

186. 8 U.S.C. $\S 1101(\mathrm{a})(15)(\mathrm{T})(2012)$.

187. 8 U.S.C. $\S 1101$ (a)(15)(T)(III)(aa) (2012).

188. 8 U.S.C. $\S 1101(\mathrm{a})(15)(\mathrm{T})(\mathrm{III})(\mathrm{bb})-(\mathrm{cc})(2012)$. 
enforcement certification is not required to obtain a $T$ visa. Applicants may instead submit "secondary evidence of compliance with reasonable requests for assistance." $" 189$

Relatedly, as discussed in Section I.A, when a U visa holder applies for lawful permanent resident status, she must demonstrate to USCIS that she has "not unreasonably refused to provide assistance to ... a law enforcement agency ... after [she] was granted U nonimmigrant status." ${ }^{\prime 190}$ An applicant can establish this continuing assistance by providing a newly executed I-918B Certification Form. However, USCIS will also accept alternative forms of proof, including an affidavit describing efforts to obtain a newly executed Form I-918B, "or other evidence describing whether or not the alien received any request to provide assistance in a criminal investigation or prosecution, and the alien's response to any such request." 191 Additionally, the regulations do not automatically disqualify applicants who refused to comply with law enforcement's requests for assistance from eligibility for adjustment of status, instead allowing them to provide USCIS with an explanation for their lack of cooperation and their belief that the requests for assistance were unreasonable. ${ }^{192}$

The $U$ visa requirements could be rewritten to incorporate exceptions, similar to those that exist for the $\mathrm{T}$ visa and $\mathrm{U}$ adjustment of status, for survivors who are too traumatized to engage with law enforcement, whose safety or security would be compromised by reporting or cooperating, or who can demonstrate that a law enforcement agency arbitrarily or unreasonably refused to sign a certification form. Allowing survivors who fall into these limited categories to be eligible for a $U$ visa without submitting the law enforcement certification form would be an appropriate mechanism for allowing victims of domestic violence who deem it too dangerous to work with the police or prosecutors to receive immigration relief and protection. And because the optout provision would be an exception as opposed to the rule, the balance envisioned by Congress could still be achieved: benefits would accrue to law enforcement in the majority of cases, while genuine victims for whom engagement with authorities is impossible would still receive justice.

Providing an exception to the cooperation requirement would not necessarily compromise the U visa's goal of assisting law enforcement. First, any victims who do not have concerns about working with police would still be able and required to do so. Second, the grant of $U$ nonimmigrant status to a survivor of

189. Questions and Answers: Victims of Human Trafficking, T Nonimmigrant Status, U.S. CITIZENSHIP AND IMMIGR. SERVS., https://www.uscis.gov/humanitarian/victims-human-trafficking-other-crimes /victims-human-trafficking-t-nonimmigrant-status/questions-and-answers-victims-humantrafficking-t-nonimmigrant-status-0 [https://perma.cc/KUG7-8CG2] (last visited Feb. 25, 2018).

190. 8 C.F.R. $\$ 245.24($ b)(5) (2016).

191. Id. (e)(2).

192. Id. (e)(2)(ii). 
domestic violence does not in fact preclude future assistance to law enforcement but might actually encourage it. Once a victim regularizes her immigration status and obtains work authorization, many barriers addressed in Section III to reporting may no longer exist. Her fear of arrest and deportation would likely subside, and she would be less isolated, more financially stable, and importantly, safe and free from her abuser. The resulting strength and stability could be a significant motivating factor for aiding law enforcement in the arrest and prosecution of her abuser.

Such an accommodation for certain survivors would be consistent with modern feminists' aims to dispel the notion that "there is a monolithic 'women's experience' that can be described independent of other facets of experience like race, class, and sexual orientation." 193 Scholars have argued that when there is room for only one female experience, it is the white experience that prevails. As Professor Kimberlé Crenshaw explains, "[n]ot only are women of color ... overlooked [in feminist theory], but their exclusion is reinforced when white women speak for and as women." 194 Providing a mechanism for certain survivors of domestic violence seeking the U visa to achieve status and security without engaging with law enforcement, or engage in a way that actually makes them safer, recognizes that the experience of victimization is not universal and allows for individualized approaches and remedies, thereby working to correct the essentialism that has long pervaded feminist theory.

More broadly, rethinking $\mathrm{U}$ visa eligibility criteria is an opportunity to examine inaccurate and polarizing narratives that exist in discourse around immigration law. Contrary to public opinion, funding for immigration enforcement is at historic levels. According to the Migration Policy Institute, spending on immigration enforcement more than quadrupled between 1985 and $2002 .{ }^{195}$ A 2017 report by the American Immigration Council revealed that "since the last major overhaul of the U.S. immigration system in 1986, the federal government has spent an estimated \$263 billion on immigration enforcement." ${ }^{196}$ Despite the enormous resources dedicated to the enforcement of immigration laws in the United States, calls for increases in spending remain.

193. Angela P. Harris, Race and Essentialism in Feminist Legal Theory, 42 STAN. L. REV. 581, 588 (1990).

194. Kimberlé Crenshaw, Demarginalizing the Intersection of Race and Sex: A Black Feminist Critique of Antidiscrimination Doctrine, Feminist Theory and Antiracist Politics, 1989 U CHI. LEGAL F. 139, 154 (1989) (emphasis in original).

195. Migration POLICY INST., No. 10: IMMIGRATION ENFORCEMENT SPENDING SINCE IRCA (2005), available at http://www.migrationpolicy.org/research/immigration-enforcement-spending-irca [https://perma.cc/2H67-QU46]. The report explains that during the relevant time period "interior investigations increased by $\$ 349$ million (320 percent)." Id.

196. AM. IMMIGRATION COUNCIL, THE COST OF IMMIGRATION ENFORCEMENT AND BORDER SECURITY (2017), available at https://www.americanimmigrationcouncil.org/research/the-cost-ofimmigration-enforcement-and-border-security [https://perma.cc/6EMY-SWTQ]. 
The Trump administration's budgets have proposed significant additional spending in the area. ${ }^{197}$

Through the lens of the $\mathrm{U}$ visa, questions about the necessity and utility of such appropriations can be more easily understood. Funding for immigration enforcement often draws critical resources away from other areas of the immigration system-for example, the already-overburdened court system or victim-advocate programs. ${ }^{198} \mathrm{~A}$ myopic focus on enforcement also suggests that immigration law is, or should be, synonymous with immigration enforcement. As this article demonstrates, serious concerns exist with respect to the efficacy and appropriateness of law enforcement seeking to aid immigrant victims. Thus, considering reforms of the $U$ visa that delink immigration status from engagement with law enforcement may be a one step toward a broader uncoupling of immigration policy and immigration enforcement.

Relatedly, the intense discussions about immigration law and policy currently taking place in the United States make this an opportune time to consider the narratives and tradeoffs that often exist in legislative reform. As Professor Hiroshi Motomura notes, discussions "about the way immigration law treats ... victims of domestic violence, trafficking, and other criminal activity amounts to a debate about whether to protect these migrants, even if they lack lawful presence, by deciding to treat them-and indeed, to imagine themoutside the category of 'illegal aliens." 199 This conceptualization prioritizes the rights of immigrant victims over the lives of "other" immigrants. Professor Elizabeth Keyes, however, questions such an approach: "[i]f worthiness is the way that these immigrants of color are able to claim citizenship-if the politics demand that high burden-does that open the door to denying citizenship to those deemed unworthy?"200

The narrative of worthy versus unworthy immigrants parallels that between ideal and imperfect victims. Feminist scholars have long decried the legal system's disparate treatment of survivors who do not conform to the normative

197. Julie H. Davis \& Ron Nixon, Trump Budget Takes Broad Aim at Undocumented Immigrants, N.Y. TIMES, May 25, 2017, at A16, available at https:/www.nytimes.com/2017/05/25/us/politics /undocumented-immigrants-trump-budget-wall.html [https://perma.cc/J5ET-B54M].

198. Editorial, Trump's Aggressive Immigration Enforcement Is Overwhelming an Already Taxed Court System, L.A. TIMES, June 30, 2017, http://www.latimes.com/opinion/editorials/la-ed-trumpimmigration-courts-deportations-20170630-story.html [https://perma.cc/FR7X-TQ35].

199. Hiroshi Motomura, What Is "Comprehensive Immigration Reform"? Taking the Long View, 63 ARK. L. REV. 225, 236 (2010).

200. Elizabeth Keyes, Defining American: The DREAM Act, Immigration Reform and Citizenship, 14 NEV. L.J. 101, 141 (2013). Professor Keyes describes narratives surrounding DREAMers, noting that "in emphasizing that the DREAMers entered through no fault of their own, the people who brought them [most often, their parents] here are thus implicitly differentiated and criticized." Id. at 143. 
ideal of a pitiable white victim lacking in agency. ${ }^{201}$ Women who have endured domestic violence often act in noble and laudable ways, but they also make "bad" decisions, either related to or separate from the abuse they have suffered. In prioritizing remedies for "ideal" victims, or those who are deemed worthy due to their assistance to law enforcement, the immigration system perpetuates harmful narratives about both survivors and immigrants. Advocates should therefore remain steadfast in their demand that visas for crime victims not be achieved at the expense of benefits for other immigrant populations, in order to avoid such damaging, and in today's political climate perhaps even self-defeating, narratives.

Returning to practical considerations, even if the $U$ visa retains its law enforcement certification requirement, there are ways to mitigate its negative impacts. The U.S. Citizenship and Immigration Services currently provides resources and information to law enforcement about the $U$ visa, but while it encourages local agencies to participate in the $U$ visa program, it does not require them to do so. ${ }^{202}$ The federal government could take a more active role and mandate the participation of law enforcement agencies. While USCIS likely could not force local officials to sign individual $U$ visa certifications, as such a determination is best left in the hands of those who are most familiar with a victim's situation, it could require localities to designate certifiers within their relevant agencies, direct that the certifiers receive appropriate education and training, ${ }^{203}$ and maintain a national database of designated and trained certifiers. New or updated DHS policy memoranda would also go a long way towards providing additional guidance to law enforcement agencies. Although this proposal would not solve all the problems discussed in this article, ensuring that

201. See, e.g., Andrea L. Dennis \& Carol E. Jordan, Encouraging Victims: Responding to a Recent Study of Battered Women Who Commit Crimes, 15 NEV. L.J. 1 (2014); Leigh Goodmark, When Is a Battered Woman Not a Battered Woman? When She Fights Back, 20 YALE J.L. \& FEMINISM 75 (2008) (explaining how women who fight back are often not viewed as victims); Aya Gruber, $A$ "Neo-Feminist" Assessment of Rape and Domestic Violence Law Reform, 15 J. GENDER RACE \& JUST. 583 (2012); Laurie S. Kohn, Barriers to Reliable Credibility Assessments: Domestic Violence Victim-Witnesses, 11 AM. U. J. GENDER \& SOC. POL'Y \& L. 733 (2003); Natalie Nanasi, Domestic Violence Asylum and the Perpetuation of the Victimization Narrative, 78 OHIO ST. L.J. 733 (2017); Leti Volpp, (Mis)Identifying Culture: Asian Women and the "Cultural Defense", 17 HARV. WOMEN'S L.J. 57 (1994).

202. See U.S. CitIZENSHIP AND IMMIGRATION SERVS., INFORMATION FOR LAW ENFORCEMENT AGENCIES AND JUDGES, https://www.uscis.gov/tools/resources/information-law-enforcementagencies-and-judges [https://perma.cc/AX2E-J8GG] (last visited Oct. 27, 2017).

203. A particularly useful area of training would call attention to the temporal flexibility in the helpfulness requirement. Although the statute contemplates a range of assistance to law enforcement-that the applicant has been helpful (in the past), is currently being helpful, or is likely to be helpful (in the future)-in practice, most agencies will not certify a case where, for example, the victim has reported a crime but no arrest can yet be made. While USCIS provides some guidance to law enforcement on this issue, further training would go a long way in ensuring that the full extent of protection is made available to all victims. See U VISA LAW ENFORCEMENT CERTIFICATION GUIDE FOR FEDERAL, STATE, LOCAL, TRIBAL AND TERRITORIAL LAW ENFORCEMENT, supra note 22, at 10-14. 
an adequately trained official conducts a fair review of a $U$ visa certification request would provide a level of certainty to applicants, eradicate geographic roulette, and eliminate some risk of deportation and arrest for survivors.

Finally, if the federal government is unable or unwilling to take action to restore the appropriate balance between law enforcement and survivors' safety and needs, states could take action to achieve the proper equilibrium. In fact, some have already begun to do so. In 2015 , S.B. 674 , which mandates the participation of law enforcement agencies in the $U$ visa certification process, was signed into law in California. The law requires agencies to provide certifications to victims who meet the federal standard of helpfulness ("have been helpful, are being helpful, or are likely to be helpful in the detection, investigation, or prosecution of certain crimes"), establishes a rebuttable presumption that victims who have not refused to provide information or assistance have met the requisite level of helpfulness for certification, and requires requests for certifications to be processed within 90 days. The law also mandates that law enforcement agencies provide information to the legislature on the number of certifications signed and the number of certification requests denied..$^{204}$

Other state legislatures have introduced similar bills, including Maryland, ${ }^{205}$ Minnesota, ${ }^{206}$ and Washington. ${ }^{207}$ The Nebraska legislature passed a resolution to study law enforcement policies and practices in that state and determine whether any legislation is needed to encourage or require agencies to certify victims. ${ }^{208}$ Local governments have done their part as well. For example, in an effort to ensure consistency for victims, the City of New York promulgated a rule that details the process for requesting certifications, provides a timetable within which requests are processed, and specifies the process for appeals. ${ }^{209}$

\section{CONCLUSION}

With the benefit of hindsight, it should have perhaps been obvious that the $U$ visa's law enforcement certification requirement would cause what was intended to be a humanitarian remedy for survivors of domestic violence to become yet another forced or coercive engagement with the state that potentially places victims at greater risk. Scholars, activists, and advocates have for decades argued that such interventions are harmful and that the pendulum had swung too

204. S.B. 674 (Ca. 2015) (codified at Cal. Penal Code $§ 679.10$ (2016)).

205. S.B. 1023, Leg. 436th Sess. (Md. 2016).

206. S.B. 3331, 2015-16 Leg. 89th Sess. (Mn. 2016); H.F. 3656, 2015-16 Leg. 89th Sess. (Mn. 2016).

207. H.B. 2895, 64th Leg., Reg. Sess. (Wa. 2016); H.B. 2912, 64th Leg., Reg. Sess. (Wa. 2016).

208. Legis. Res. 549, 104th Leg. 2d Sess. (Ne. 2016).

209. N.Y.C., N.Y., 38 Rules of City of New York $\$ 22-04$ (2016), https://rules.cityofnewyork.us/content /requesting-certifications-u-nonimmigrant-status-u-certifications [https://perma.cc/6X9M-RWN2]. 
far in favor of prosecution and away from victim autonomy and safety, yet the $U$ visa fell into the familiar trap of requiring survivors to cooperate with law enforcement. The solutions proposed in this article would mitigate the harmful effects of the $U$ visa certification requirement and break away from old and ineffective conventions surrounding assistance for survivors of domestic violence.

Since the 1970s, there has been a significant positive shift in the recognition of the severity of the problem of domestic violence. Both the general public and law enforcement have made great strides in understanding that intimate partner abuse is not simply a family matter, but as serious as any other assaultive or violent crime. As society has achieved a more sophisticated understanding of domestic violence, it is now time to scale back the mandatory interventions that were originally enacted to ensure equity for victims. Such mitigation is particularly warranted because "[v]ictims consist of individuals of different races, socio-economic levels, and social statuses who have been affected to varying degrees by crime." ${ }^{\text {210 }}$ The protections provided by police, prosecutors and the legal system can be lifesaving for many victims of domestic violence, but such intervention is not appropriate for all. Finding nuance and mediating the detrimental effects of forced state interaction is the least we could do for immigrant survivors. 